\title{
István OLAJOs* \\ The special asset management right of nature conservation areas, the principal of the prohibition of regression and the conflict with the ownership right in connection with the management of state-owned areas**
}

\section{The constitutional basis of nature conservation}

The problems of nature conservation state areas were occured in the hungarian law firstly by the implementation of transitional act on cooperatives. When the nature conservation regulations became general and related to the establishment of the system of national parks, a principle, wherein together with the territorial protection, a special management right is created for the directorates of national park on the restricted areas of the national park, immediately appeared. In these areas, by the properly validation the principle of territorial protection, related to the use of land, it will be under the nature conservation interest. In practise it meant, that for example in the area of Hortobágy National Park, if a special non-replaceable ecosystem was created on an artificially established pond, then in the interest of nature conservation, after the condemnation proceeding, the intensive fisheries management incompatible with ecosystem protection was become prohibited. ${ }^{1}$

This proceeding until the change of regime (I mean the ratification of the act of 1991 on compensation, ${ }^{2}$ the act of 1991 on transformation of cooperatives, ${ }^{3}$ the act of

István Olajos: The special asset management right of nature conservation areas, the principal of the prohibition of regression and the conflict with the ownership right in connection with the management of state-owned areas - A természeti védettség alatt álló területek speciális kezelői joga, és a visszalépés tilalmának elve, valamint a tulajdonosi joggyakorlás jogának ütközése az állami tulajdonú területek kezelése kapcsán. Journal of Agricultural and Environmental Law ISSN 1788-6171, 2018 Vol. XIII No. 25 pp. 157-189 doi: 10.21029/JAEL.2018.25.157

* dr. jur., PhD, associate professor, University of Miskolc, Faculty of Law, Department of Agricultural and Labour Law, e-mail: civoliga@uni-miskolc.hu

** This study has been written as part of the Ministry of Justice programme aiming to raise the standard of law education.

${ }^{1}$ See the promotion process of the branch office of Hortobágyi Halgazdaság Ltd. to be a national park core area between 1993 and 1996.

2 See about the compensation, as a process and the legal aspect processing of compensation: Kovács Csaba: Átalakítás vagy szétverés?: a szocialista jellegű mezőgazdaság végnapjai és a kárpótlás utáni gazdálkodás néhány sajátossága, Levéltári Közlemények, 2011/1, 239-260.; Gulácsy Katalin: A kártérítés, a kártalanítás és a kárpótlás adójogi megítélése, Adó, 2009/8., 15-18.; Menczer Gusztáv: A kárpótlás, mint jogintézmény, Gazdaság és Jog, 2005/4, 13-19.; Szirmai Márton: A magyar kárpótlás gyakorlati problémái, Tudományos Közlemények, 2000/2. 167.; Fertô Imre - Mohácsi Kálmán: A politikai kárpótlás folyamata és következményei, Európa Fórum, 1996/2, 85-106.

3 See about the transformation of cooperatives: Karner Ottó: Átalakulás és múködés (Szövetkezeti jogi praktikum), Gaz̧daság és Jog, 1998/2, 21-23.; Becz Miklós: A szövetkezeti 
1992 on cooperatives and the act of 1993 on land allocation and land settlement committees ${ }^{4}$ under change of regime) was a relatively simple process, because under the legal framework of land act built upon the primacy of state and cooperative property, this proceeding, by which this nature conservation of public wealth management prevailed, with a simple land exchange, could be solved ignored by the condemnation proceeding.

The act on compensation, the act on transformation of cooperatives and the act of 1992 on cooperatives are the basis of change of regime, and in the processes of these acts, the nature conservation regulation is only secondary applied. The essence of regulation is that in addition to the abolition of cooperative property, the cooperative land property shall direct to a compensation member-employee, member and state land fund.

Related to the designation of land funds, the cooperative had absolutely no regard to its own concluded contracts, so for several years, areas be in plantation settlement and in others' exclusive use were also designated to the compensation fund. In case of this proceeding, other restrictions such as restrictions granted to nature conservation of land use, have not been taken into account. ${ }^{5}$ So the nature conservation areas could be privately owned in such a way, that with a special land use clause, the new owner was only informed from a later provision restricting its ownership and made by national parks directorates.

átalakulás, Gazdálkodás, 1994/1, 17-22.; Varga Gyula: A mezőgazdaság és a szövetkezetek átalakulása, Társadalmi Szemle, 1993/4, 32-41., Váradi Monika Mária: Keskeny az ösvény. Esettanulmány a 'Harmónia' Mgtsz átalakulásáról, Replika: sqociológiai viták és kritikák, 1998/3334, 121-135.; Rácz Zoltán - Kenderes György - Tatár Irén - Szilágyi Sándor: Mezơogazdasági szövetkęetek átalakulási kérįikönyve, Miskolc, Regiocon, 1992, 227.

4 Welcome address of state secretary on "Részarány földkiadás során keletkezett osztatlan közös tulajdon megszüntetése projekt tapasztalatai" conference, Geodézia és kartográfia, 2015/11-12, 28.; Halász Imre László: Gondolatok és tapasztalatok a részarány földkiadás során keletkezett osztatlan közös tulajdon megszüntetésének eljárásáról, Geodézia és kartográfia, 2006/11, 37-39.; Only the statutory decision of the land allocation committee is qualified as a substantive decision, only those can be reviewed by the court: Act II of 1993 6. \, 11. \(1) Points a)-d), Körigazgatási-Gazdasági Döntvénytár, 1996/5, 71-72.; The land allocation committees work as an authority defined by the law: Act III of 1993 11. \, Közigazgatási-Gazdasági Döntvénytár, 1999/3, 57.; The purchase right of lessee cannot be exercised in respect of a real estate property setting out to the shared land fund. The annuling decision on the decision of land allocation committee on land allocation does not give rise to a right in good faith: Curia (Supreme Court of Justice) Kfv. VI. 28 309/1998, Köæigazgatási-Gazdasági Döntvénytár, 2004/4, 27-31.

${ }^{5}$ See Act L of 1992 4. J: For the purposes of compensation land fund, a nature conservation area may be appointed except a nature conservation core area and an area under nature conservation based on international convention. This modification mitigated the provisions of Act II of 1992 and the parallel Act XXVI of 1991, which gave the nature conservation area to the treatment of the national park directorates and required to replace these areas with state exchange land. 
The conflict of the two types of land use and two approaches which are the base of land use was realised and interpreted by the Constitutional Court of first period in its Constitutional Court Decision no. 28/1994 (V.20.) which is the base of the principal of the prohibition of regression. ${ }^{6}$ The application, which is the base of the aforementioned decision, based on the provision, which determines that a nature conservation area can be designated to the compensation land fund to satisfy the increased compensation claims. Here the regression was perfectly contrary to an established nature conservation regulation and practice. The nature conservation regulatory was in the background against the increasingly applied compensation claims, which the government tended to accept. However, the nature conservation management of lands has been the part of the Hungarian legal system since the 1970s. At the time of the establishment of our environmental regulation, the President of the Constitutional Court, László Sólyom ${ }^{7}$ - in his own legislature practise - realized how difficult it was to develop the emergence of a nature conservation approach in case of land use. He considered the special asset management right of national parks such a value, which was qualified as a retained value and was to be considered as an important, institutional and unique legislation of the hungarian environmental protection legislation.

The aforementioned Consitutional Court Decision no. 28/1994. (V.20.) considered the right to a healthy environment not only a subjective fundamental right, but also"independent and self-contained protection of institutions."

\footnotetext{
${ }^{6}$ See about the interpretation of the prohibition of regression: Fodor László: A visszalépés tilalmának értelmezése a környezetvédelmi szabályozás körében, Collectio Iuridica Universitatis Debreceniensis, 2006/6, 109-131.; Halmos Gergő: Ne legyen visszalépés! Madártávlat, 2015/2, 3.; Bándi Gyula: Környezeti értékek, valamint a visszalépés tilalmának értelmezése, Iustum Aequum Salutare, 2017/2, 159-181.; Csák Csilla: Környezetjog, Novotni kiadó, 2009, Miskolc; furthermore see about the whole monographic evaluation of this area: Fodor László: Környezetvédelem az alkotmányban Gondolat kiadó, Debrecen, 2006, 106-163.

${ }^{7}$ Sólyom László környezetjogi jellegú írásai a következők: Sólyom László: The Rights of Future Generations, and Representing them in the Present Acta Juridica Hungarica, 2002/1-2, 135143.; Sólyom László: A jövő nemzedékek jogai és ezek képviselete a jelenben, in: Jávor Benedek (edit.): A jövő nemzedékek jogai, Védegylet, Budapest, 2000, 37-46.; Sólyom László - Szabó Máté (edit.): A Zöld Hullám: Olvasókönyv a környezetvédelmi társadalmi mozgalmakról, Budapest, ELTE, 1988, 282.; Sólyom László: A környezeti kockázatok elosztásának néhány előkérdése, Jogtudományi Közlöny, 1987/5, 221-226.; Sólyom László: Hans Engelhardt: Bürger und Umwelt, Jogtudományi Közlöny, 1986/10, 510-511.; Sólyom László: A társadalom részvétele a környezetvédelemben, Medvetánc, 1985/5-6, 217-242.; Sólyom László: A polgári jogi bíróságok környezetvédelmi ítélkezése és a polgári jog lehetőségei a környezetvédelemben, in: Trócsányi László (edit.): Környezetvédelem és a jog, Budapest, Akadémiai Kiadó, 1981, 148-179.; Sólyom László: Der zivilrechtliche Umweltschutz und die Möglichkeit einer Bürgerklage im ungarischen Recht, Acta Juridica Academiae Scientiarum Hungaricae, 1980/1-2, 19-55.; Sólyom László: Környezetvédelem és polgári jog, Budapest, Akadémiai Kiadó, 1980, 170.; Sólyom László: Egy környezetvédelmi populáris akció elvi lehetősége polgári jogunkban, Jogtudományi Közlöny, 1978/11, 672-682.; Sólyom László: Biztosítás és egyéb technikák a környezeti károk fedezésére, Állam- és Jogtudomány, 1978/3, 306-338.
} 
In connection with this, it increased the fulfillment of the state's environmental protection obligations and its guarantees to the level of fundamental rights. "The State does not reduce the degree of the protection of nature as guaranteed under law, unless this is unavoidable in order to enforce any other fundamental right or constitutional value. Even in the latter event, the point to which the degree of protection is reduced cannot be disproportionate to the goal to be achieved." The Consitutional Court defined the principle of the prohibition of regression in such a way, which has since been continuously prevailed in the jurisprudence of the Constitutional Court and is one of the greatest limit of the state's environmental protection activity. Later this right extended to the protection of the built environment (Constitutional Court Decision no. 27/1995. (V.15.), and this right also meant the opportunity of the significant restriction of ownership for environmental protection reason (Constitutional Court Decision no. 64/1993. (XII.22.). ${ }^{10}$ From this principle it is deducible that the environmental interest can not be subordinated to the regional development interest: the important is to maintain the balance between the development of economy and environmental interest.

The adopted text of the Fundamental Law of Hungary was required the reinterpretation of the own role of Constitutional Court. Where the Fundamental Law relieved the liability of the state for fundamental rights, there the judges did not follow the stricter interpretations of their predecessors. Whereas the environmental protection, beyond the National Avowal, also appears in Fundamental Law of Hungary Article P and Article XXI with a stronger content than in the Constitution, thus related to this area, the Constitutional Court determined in its Constitutional Court Decision no. 3068/2013. (VI.17.), that the Constitutional Court accepts to be bound by its previous decisions. This can be deducted from that "the Fundamental Law of Hungary contains significantly more provision compared with the Constitution, so the Fundamental Law of Hungary can be considered the development of Constitution." 11

\section{May special asset management right of national parks be considered as a basic institution?}

Next time, the issue has been raised related to the Constitutional Court Decision no. 16/2015. (VI.5.). The question for Constitutional Court was, whether regarding the protected areas there is any right to the legislator to transfer the asset management right of a nature protection area to the National Land Fund with the introduction of Act CCIV of 2015 on the Modifications of Acts on Management of State Land Asset (hereinafter referred to as Módtv.).

8 Constitutional Court Decision no. 28/1994. (V.20) 134. és 138., and Sulyok Katalin: Az Alkotmánybíróság elózetes normakontroll döntése a nemzeti park igazgatóságok vagyonkezelői jogkörének csorbítása tárgyában (hereinafter referred to as Sulyok 2015, 19).

${ }_{9}$ Constitutional Court Decision no. 28/1994. (V.20) 141.

${ }^{10}$ Sulyok 2015, 19.

${ }^{11}$ Sulyok 2015, 19. 
The rules of environmental protection asset management are regulated by the Governmental Decree no. 262/2010 (XI.17.) (hereinafter referred to as Nfavhr.) 43/A and $43 / \mathrm{B} \int$, as the follows:

"The primary purpose of nature protection asset management is the implementation of nature protection public purposes on state owned lands, the conservation of living and inanimate natural values, the preservation of landscape and cultural historical values, the preservation of the consistency and value of nature wealth, furthermore the enlargement of the valuse of nature wealth in a sustainable way. In the case of nature protection asset management, the Agricultural and Forestry activity (bereinafter referred to as activity) in the field of protected area can be done with respect to nature protection aims. The application of traditional (landscape-nature), nature-friendly, close-to-nature activities should be privileged, the sustainability of the indigenous and domesticated animals as a gene reservation shall be ensured and the area sustainability and care of protected area according to the nature conservation interests in the way of livestock (in case of appropriate headcount, species and variety composition).

The national park directorate (hereinafter referred to as directorate) keeps the registry of asset management protected areas up-to-date in the Nature Conservation Information System.

The directorate carries out its asset management activity taking into consideration the longterm (10-year-old) nature conservation asset management plan approved by the minister of nature conservation and the annual nature conservation asset management plan prepared based on the aforementioned plan.

The directorate related to the protected area be in its own asset management or get into its own asset management, exercises the right of possession, use and utilization (bereinafter referred to as own use), if

(a) The protected area is an area, which is under nature conservation protection covered by climax and similar communities, in which farming activity is not possible because of the nature conservation aspects (significantly important, protected nature areas and values) or which does not require nature conservation maintenance activity, therefore, the utilization of protected area is prohibited or highly limited (in particular, some biosphere reserves core areas, scientific reserves, some natural areas, some highly protected natural areas).

(b) In the protected area, the validation of the nature conservation interests requires special activity or existence of special knowledge or equipment and without them the leasing of protected area would be expected to endanger the destruction of natural values, threat or dissolution of their growth.

(c) If in the protected area the nautre conservation targets is rationally manageable with the equipments and personnel possessed and realistically obtainable by the directorate in accordance with the other state functions of the directorate, and there are indispensable for the maintenance and catering of the livestock, provision and maintenance of livestock be in the ownership, asset management and use of directorate.

(d) According to the real estate registry the protected area is registered in the forest cultivation branch or in the absence of it, for which the legal nature fact of the protected area, registered in the National Forestry Database as a forest, is registered in the real estate registry, and according to the National Forestry Database this protected area is primarily qualified as an economic purpose forest.

(e) The nature conservation authority suspended the recovery obligation in the protected area." 
Analyzing the aforementioned provisions: a possible way of asset management is that the directorate assigned for the asset management leases out the state owned areas to others. The other possible way is that the directorate can solve the asset management with its own equipments, if a special protection is registered to the area, if the area is a forest or if in the protected area, the recovery obligation required to an other farmer was suspended because it was not adequate.

According to the Módtv. 1-6. S, the special right of asset management is ended and regarding to the general rules the National Land Fund could have exercised the right of asset management and preemptive right based on the 8 . $\int$ on these areas. On the other areas, the right of asset management would have been restricted to areas which are directly connected to the completion of the basic duties of national park directorates or be directly in their deed of foundation or statutes. ${ }^{12}$

Interpreting this provision, the National Land Fund does not get nature conservation asset management, this institution is ended and merges into the general asset management, which is previously belonged to the National Land Fund. This statement is not correct perfectly, because the general right of asset management is extended a preemptive right, and on the nature conservation core areas and related to the completion of its duties, it is remained in the scope of the national parks. So the national park, if this regulation would have entered into force, would have exercised its nature conservation regulatory and restrictive activity only at the highest level of the nature conservation and it would not have had the right to expand the nature conservation, monitoring the changes in the natural environment, to areas owned by others or be in others' asset management. So the opportunities to expansion would be strongly bounded. The regulation would lose not only its legal framework, but at least minimize it, but the land use zone system, which is considered as one basis of

\footnotetext{
12 Constitutional Court Decision no. 16/2015 (VI.5) 4-9.
} 
agricultural-environmental protection since its elaboration 1999, made based on the land use pyramid scheme would have fallen. ${ }^{13}$

As the scientific basis of zone system, the lands of Hungary simultaneously undergoes an environmental rating, which grounds an agricultural economic use and determines the nature conservation level of lands. Such areas, which are qualified important in nature conservation aspect beyond economic aspects, according to the current rating, can require further support in order that these areas maintain their nature conservation character. In these areas, agricultural-environmental economic or Natura 2000 based supports can be required beyond the the production and the related agricultural basic supports, which condition is the takeover of the nature conservation activity be typify to the special area from the state beyond the continuation of production.

13 Ángyán József - Podmaniczky László - Ónodi Gábor: Agrár-környezetgazdálkodás és vidékfejlesztés: az európai agrárfinanszírozás új útja a gyakorló gazda szemszögéből, Falu Város Régió, 2003/8, 3-12.; Pálvölgyi Kálmán: Mit tehet az agrár-környezetgazdálkodásban (AKG) résztvevő gazdálkodó, ha nem tudja, vagy nem akarja vállalni a szerződésben foglalt kötelezettségeit?, Agrárágazat, 2006/8, 8-9.; Dömsödi János: A földértékelés, földminősítés módszertani elemzése, rendszerezése, továbbfejlesztése, Geodézia és Kartográfia, 2007/3. 26-33.; Szilágyi János Ede: Common Agricultural Policy, new rules of WTO and regional equilibrium Hungarian National Report, Agrár- és Környezetjog, 2008/5, 3-18.; Farkas Csamangó Erika: Az agrár-környezetgazdálkodás alapjai, Acta Universitatis S regediensis: Acta juridica et politica, 2008/1-17, 151-182.; Gyarmati Ágnes: Az agrár-környezetgazdálkodás támogatása a Nemzeti Vidékfejlesztési Terv bevezetése kapcsán, Agrártudományi közlemények = Acta Agraria Debreceniensis, 2006/20, 52-59.; Csák Csilla - Olajos István: The application of the single payment by national administrations and national courts - Hungarian National Report, Agrár-és Környezetjog, 2008/5, 31-42.; Szilágyi János Ede: Magyar Nemzeti Jelentés a gazdálkodók tevékenységének diverzifikációját érintő jogi ösztönzőkről és jogi akadályokról, Agrár-és Környezetjog, 2010/8, 3-48.; Horváth Gergely: Gondnokság - Az agrár-környezetjog funkciója és felépítése, Jog, Állam, Politika, 2012/2, 107-127.; Csák Csilla: Cross compliance, avagy környezetvédelem a támogatás feltételeként, Publicationes Universitatis Miskolcinensis. Sectio Juridica et Politica, 2012/2, 423-433.; Csák Csilla: A fenntartható természeti erőforrás-gazdálkodás jogi szabályozása, Müsz̨aki Földtudományi Közৃlemények, 2013/2, 73-86.; Marticsek József - Molnár Dániel - Mozsgai Katalin - Podmaniczky László - Skutai Julianna - Tóth Péter: Az agrárkörnyezetgazdálkodási támogatási rendszer fejlesztési lehetőségei (Hogyan tovább agrárkörnyezetgazdálkodás?), Természetvédelmi Közlemények, 2015/21; 232-242. 
Here, the producer undertakes state environmental protection tasks beyond the limitation of his/her own production and carries out state environmental protection tasks, and the this special support is for the cover of the costs of environmental protection as the part of the Rural Development Operational Program. ${ }^{14}$ The factual control of the performance of the tasks and the strengthening or weakening of the related producer obligation in accordance with the changing environment were determined and verified by the national park directorates.

If the producer could no longer meet the tightening environmental standards, he/she could have requested the condemnation of his/her area based on the Act XCIII of 1995 on the Restoration of Protection Level (hereinafter referred to as Vszt.) and after the payment of compensation amount, the special asset management right of national park directorates was registered to the mentioned area as a state ownership.

Based on the consensus of the land user and the national park directorates, who required the condemnation and had the amount of compensation costs, this was only initiatable after the payment of complete, immediate and unconditional compensation cost. The amount of condemnation was always determined by the budget resources available for nature conservation. ${ }^{15}$

This possibility of the initiation of the condemnation would have been ended in case of the acceptance of Módtv. and would have been the competence of the National Land Fund, which conducts a defensive state land policy (see "Földet a gazdáknak" program, "Land for farmers" programme). This opportunity would have not led to the further expansion of state property, however it would have been together with the additional reduction of nature conservation role because the task definition and controlled function of national park directorates, who have lost their separate ministry structure, is also reduced and the possibility of nature conservation asset management is restricted only to the core area.

\footnotetext{
${ }^{14}$ Hegyes Péter: Links Between Rural Development and Direct Payments Based on the "CAP Reform” of 2013, Agrár- és Környezetjog, 2014/17, 39-49.; Andréka Tamás - Bányai Orsolya Olajos István: The most changes of the Hungarian Agricultural Market Policy after the 2013th CAP reform, Agrár-és Környezetjog, 2015/19, 6-18.; Gyurán Ildikó - Olajos István: Magyar Nemzeti Jelentés - Földhasználat és földvédelem a tagállamok jogában, The Hungarian National Report on Rural Use and Protection of Land in the Countryside, Agrár- és Környezetjog, 2012/12, 79.; Olajos István: The provisions of the Rural Development in connection with the agriculture in Hungary, Agrár-és Körmyezetjog, 2006/1, 3.

15 Andorkó Imre: A kisajátítás a tulajdonjog korlátainak rendszerében Iustum aequum salutare, 2013/2, 241-253.; Horváth Paula: Néhány gondolat a kényszeradásvétel (kisajátítás) tervbe vett új szabályozásához, Magyar Köæigazgatás, 2005/2, 121-124.; Kampis György: A kisajátítás jogi rendezése és az új Ptk., Gazdaság és Jog, 2001/4, 18-21.; Prugberger Tamás: Adalékok a kisajátítás jogintézményének a korszerűsítéséhez, Magyar Közigazgatás, 1991/2, 176-180.
} 


\section{The dilemmas of practise of general asset management of National Land Fund and the special legal practise in the position of lessee}

Another major problem of regulation is that the general nature of the asset management right in case of asset utilization does not include nature conservation aspects and thus the scope of task and authority of the National Land Fund is not broadened. So if the nature conservation value of an area will be increased in the future, further severity of the land use would be needed, which the national park network that lost its nature conservation asset management right cannot do no longer and it also cannot be done by the National Land Fund which has not nature conservation featured scope of task and authority. So the amendment can not be interpreted as András Varga $Z$ s. (Judge of the Constitutional Court) explains in his minority report ${ }^{16}$ that there is nothing other than the rights and jurisdictions are transferred to an other state body (National Land Fund) from one of the public body (national park directorates).

Strictly interpreting we have to agree with the fact that due to the legislation change the entitlement of the nature conservation, that it can influence other persons' land use based on its own aspects, becomes difficult. The opportunity for land users, that they can join to the economic framework of the agricultural-environmental economic programme financed by the European Union, becomes narrower.

Thus the number of persons used the hungarian environmental economic supports would be significantly reduced, thus serious remaining money would be arised in the Rural Development Operative Programme. This would cause the restart of the rural development-related planning, which way through would be difficult to complete in the available two-year period until 2020.

The concerned provisions of Módtv. interfered to an extant institutional structure, deprived jurisdiction from nature conservation institution system and gave jurisdiction to Land Fund, which ensures the general agricultural asset management, in such a way, by which the area proctection and the changing opportunity of changing environment would be ceased. The general asset management right is a narrower legislation compared with the aforementioned and analized nature conservation asset management. In this area, based on the Act on National Land Fund, the state legal practitioner may rely special extra rights ensured only for him and in the exercise of these rights he can ensure special extra opportunities to his contractual party. Before the adoption of Land Transaction Act, in case of state land, the state had the right to give the state-owned land to the usage a selected personal circle in a land leasehold contract against more favourable leasehold fee than the market leasehold fees. This leasehold contract, because the compensation was less, than its real value of leasehold fee, considered a short-term, a few years contract and the National Land Fund on behalf of the state exercising the land use right could determine that it had the right to modify the amount of the leasehold fee in every two years during the term of the contract. ${ }^{17}$

\footnotetext{
${ }^{16}$ Constitutional Court Decision no. 16/2015 (VI.5) 215-218.

${ }^{17}$ See Nfavhr. 36. S
} 
After the adoption of the "Land for Farmers" programme, the land policy on the utilization of state land assets has changed, the state sold the dominant share of its land assets at the market price, the best farmer's offer was accepted in the state land auctions, who had the opportunity to repay the purchase price from discounted statesponsored bank loans. However, these bank loans typically required even more repayment instalments than the new owner of the purchased land would have been got from the previous user under the legal basis of leasehold fee. The bank, which credited his land acquisation, had already demanded the interest and the repayment installment in the month after the loan from the owner, who had not been able to perform economic activity, which was the condition of bank loan, for years because of the existing lease contract. What could the owner of the purchased land share do? Because it replaced the National Land Fund and exercised the National Land Fund's right as a lessee, it had a right to change the payable leasehold fee by its tenant. Because of it, the leasehold fee could have increased tenfold and bigger unilateral leasehold fee change was not unique in this period. The new owner had absolutely no interest in maintaining the leasehold contract, and utilising his extra opportunities ensured by the inherited contract, he would have liked to force the land user inherited by him to abandon his activity. ${ }^{18}$ It is obvious that it is impossible to recover tenfold land use fee in a determined area after a multiannual profit-oriented land use history, so the land user become insolvent was forced to abandon the land use, because if he accumulates land use fee debts, according to the adequate interpretation of relevant provisions of Land Transactions Act, ${ }^{19}$ he can not only become a lessee related to a new area, but also it is not possible to get the ownership of agricultural and forestry lands by him. The land user have two options: he initiates the termination of the existing land use contract by an opportunity of mutual agreement or brings an action referred to "clausa rebus sic stantibus" in order that the civil court decides about the content of the contract between him and the new owner. In the statement of the content, it may be an important role that in the period when the legal succession happened, none of the contractual parties had any special rights referred to the Act on National Land Fund and had the right to conclude an Act on National Land Fund based leasehold contract. The leasehold contract, according to the Land Transactions Act 38. \ on the usage rules, is on the established contractual legal title, but the special extra rights of state lessor are not applicable for the legal relationship of the parties. Thus, continuing the applicant's argument, only the lease, share-cropping and share-farming contract regulated by Land Transactions Act and the contractual clauses adapted to the Land Transactions Act could have been established by the court. One of these important clause is that the land use fee of the land use contract may only be modified by the contracting parties after five years ${ }^{20}$ and it concerns to all contracts concluded under the Land Transactions Act.

\footnotetext{
${ }^{18}$ Based on Nfavhr. 36. \, if the parties cannot agree with the increased lease fee, the leaseholder can terminate the contract.

${ }^{19}$ See Fftv. 14. \$

${ }^{20}$ See Fétv. 50/AS
} 
So if the court decides that because of the change of person, a leasehold contract due to the Nfavhr. not, but a leasehold contract due to the Fétv. can be concluded by the parties, and on this contract as a contrary with the general legislation, such clause of the contract, that the leasehold fee can be modified unilaterally every two years, and for this kind of amendment, the consent of the agricultural administrative body is necessary, which was also not in this case.

The third option, that according to the contractual freedom ensured by the Fundamental Law of Hungary, right to equitable evaluation of the cases and the principle of minimum intervention of acquired rights, the person contracted by the state may not be in a position, which entails the breach of his acquired rights. In this case, the claim concerned in the case may be challenged by the court at the level of Contitutional Court assuming the harm of the general legal principles. This happened in November 2017, when the Constitutional Court rejected constitutional complaint in a similar case.

The Constituional Court no. 27/2017. (X.25) on a completely different basis, attacks the "Land for Farmers" programme related to the undermining of the state asset connected to the cardinal laws. One of the most important element of the program is that the state sells its asset share of agriculturally usable land asset in such a way that these shares are gone to the management of farmers determined in the preamble of Land Transactions Act. In this point the state related to the implementation of land policy operating determined principles sells the significant part of its land shares acquired by the state in other ways. Related to the programme, it endeavors to the standardisation of the land ownership and land use and promotes the realisation of a fact adopted with the declaration system of Land Transactions Act, that only the person can acquire agricultural and forestry land, who is ready and able to cultivate it by its own. The petitioner criticises beyond the legislative issues, that with the operation of the programme, it shallows the Fundamental Law of Hungary Article P) in such a way, that the state owner sells its owned land. Thus it will not have a say that the national common heritage will be preservable for the future generations. In the interpretation of Constitutional Court, the protection of lands can be preservable with a complex system of rules and not limited to the principle of state ownership.

"The arable land regulation is a multiple and complex: the Act CXXIX of 2007 on the Protection of Arable Land determines the quantitative protection of the arable land, this is independent from the owner and none element is cardinal. The forests are a protected legal item highlighted and named in the Fundamental Law of Hungary Article P), but the Act XXXVII of 2009 on the Forests contains not-cardinal provisions, so that parts of this Act can be modified by a simple majority. The Land Transactions Act is wholly cardinal, and not only in its state-owned section, this Act implements the Fundamental Law of Hungary Article P) (2). Staying the state ownership of the nature conservation lands is guaranteed by the Act LIII of 1996 on the Conservation of Nature, which enables the land exchange with the similar natural value protected natural area by the the approval of the Minister, however the other ways of alienation is not allowed by the Act."21

${ }^{21}$ See the Act LIII of 1996 on the Conservation of Nature (hereinafter referred to as Tvt.) 68. \$ (8). The referred provision is arised from the Constitutional Court Decision no. 27/2017 (X.25.) Point 41. 
The Constitutional Court similar to the connected provisions of Act on Conservation of Nature interprets the analized Act XCIII of 1995 on the Restoration of the Protection Level of Protected Natural Areas as a legal institution ensured the protection of state-owned lands. In addition to this Act, the emergence of the general precautionary principle accepted in environmental law serves the retention of protected natural areas in state ownership, whereby the state shall ensure that the deterioration of the condition of the environment as a consequence of a particular measure does not occur. However related to the validation of the "Land for farmers" programme, the provision of 68. \$ (8) was consistently enforced in the land selection process, so direct sale from the nature conservation lands has not been taken place. The second essential point of the proposal was that on what the income earned from the sale of state asset protected by cardinal acts can be spent. According to the proposer, this asset can only be used for the purposes of the next generation and can not be used freely for the purposes of the state's current budget. In that regard, the Constitutional Court examined such provisions of the Act on National Land Fund. The Constitutional Court found that the burden, the providing security and providing shared ownership of the land share belonging to the National Land Fund are prohibited, however this prohibition does not apply to the transfer of ownership, so by changing the state's shareholder's share of these lands, the lands are excluded from state asset and no longer be subject to the prohibition of asset management referred to in 38. S. The sales of asset gone from the state asset is not totally free, because the subject is a forable land, which limits determined in personal, material, and obtainable quantities of land provided by the Land Transactions Act, so in the sale process the sales was and is possible in respect of the relevant regulations.

On opposite minority report was made by Ágnes Czine (Constitutional Court judge) and she concluded that "the operation of National Land Fund is utmost important for the protection of forable land and forests."According to her interpretation, the National Land Fund only complies with its destination, if the necessary equipments are available to fullfil it. The withdrawal of 203 thousand hectares of land under the "Land for Farmers" is such a loss of asset, which greatly affects the operation of the Land Fund, so the undermining of the institution's asset management duties can only be approved by a cardinal act. According to the interpretation of the constitutional court judge, the income replaced with arable land asset would have to be used for the purposes of the National Land Fund, because the withdrawal of income from sales endangers the protection of the arable land asset remained in National Land Fund and the preservation for future generations. Therefore agree with the petitioner, the constitutional court judge believes that the violation of the purpose of national asset's treatment and protection is possible.

István Stumpf constitutional court judge creates a similar viewpoint, who thinks that the sale of the national land asset and the income arised from it to the repayment of the national debt terminates the special asset nature of national land asset and the possibility that the income arised from it is spent to the special purpose of national land asset. Based on the opinion of István Stumpf constitutional court judge, the legal interpretation adopted by the majority of Constitutional Court questions the existence of Article P). 
As you can see the Constitutional Court is not uniform in that in order to the protection of Article P), what kind of safeguarding of asset's obligation the state has. It is clear based on the last two judges' opinion that the question of asset management seems to be more important in their interpretations than the enforcement of the state's agricultural policy, which effectively seeks to the standardisation of the ownership and use and it is also seeks to the land user who actually use the land and the land users ensured their own existence the agricultural production of the country be the owners of the arable lands. In my opinion this purpose is much more important than retention of supermassive areas in state ownership and with the equipments of state asset management the maintenance of a such users, who obviously farms in lands owned by others.

In my opinion, the aforementioned state purpose corresponds most to the implementation of the state agricultural policy indicated in the Preamble of the Land Transactions Act and with the consistent application of this, the functioning of the this strategic sector can be maintained and the related acquisition rules shall be controlled and maintained with the equipments of law and it shall not directly be controlled with the political impressionable equipment of the state owner's decision.

The interests of the future generation are ensured by not the high level of state land ownership, but the uniform treated private land ownership and land use. The state can protect the interests of future generations, if in case of the change of generations also creates such rules, which contribute to the maintainenance of this unit and the protection of established farm structure.

In particular related to the inheritance of the land, it does not allow the division of the established estate body possessed bodies and the breakdown of the usable estate structure. However in order to the aforementioned comes true, not the maintenance of state land management organizations, but the validation of a well designed and consistently used land inheritance system is necessary. ${ }^{22}$

\footnotetext{
22 See about the rules of special inheritance of Agricultural and Forestry Lands: Csák Csilla Hornyák Zsófia - Olajos István: Az Alkotmánybíróság határozata a mező- és erdőgazdasági földek végintézkedés útján történő örökléséről. Az örökléshez való jog sérelme, Jogesetek Magyarázata, 2018/1, under publishing; Hornyák Zsófia: Grunderwerb in Ungarn und im österreichischen Land Vorarlberg, Agrár- és Körmyezetjog, 2014/17, 62-69.; Hornyák Zsófia: Die Regeln der Erbfolge auf der Basis einer Verfügung von Todes wegen im landwirtschaftlichen Grundstückverkehr, Agrár- és Környezetjog, 2016/21, 4-27., doi: 10.21029/JAEL.2016.21.4; Hornyák Zsófia: A mezőgazdasági földek jogutódlásának anyagi jogi kérdései, Miskolci Jogi Szemle, 2017/2, 124-136.; Hornyák Zsófia: A földöröklés szabályozása egyes európai országokban, Miskolci Jogi Szemle, 2017/2, 182-188.
} 


\section{What is the matter with the asset management of lands part of the Natura 2000 system? Is the Natura 2000 area protected?}

The Constitutional Court interested in the question and the problem of the possible transfer of the nature conservation areas and pursuing the idea of petitioner, interprets the correspondence of the Governmental Decree no. 262/2010 (XI.17) on the Usage of National Land Fund's Land Shares Point 9. with the Fundamental Law of Hungary ex officio. They demanded the annulment of Point 9, because according to their statement this provision violates Fundamental Law of Hungary Article P) (1) and Article XXI. The petitioners also complain that the Governmental Decree no. 1166/2015 (IX.21) Point 1/d ("Land for Farmaers" programme) does not take out the Natura 2000 areas from the distribution circuit, which violates the emergence of principles set out in the previous sections of the article, and which require special treatment of nature conservation areas.

Related to the petition, the Constitutional Court interpreted the current system of the special rules of the Natura 2000 areas' designation. Related to its interpretation, it can be established that the Natura 200 area is the part of european-nature nature conservation system. It plays an important role to preserve the consistency between agricultural land use and nature conservation land use and in accordance with the purposes of nature conservation, operating as a biological corridor provide opportunity to the maintenance of the current level of biodiversity, if the interests of agriculture aiming to the monculture are contrary. On the natural condition close areas, the current status of biodicersity may remain with the minimal human intervention or without human intervention, and the obligation of the state related to the designation is that the designation-time protection level of the areas not reduced. On time of the designation of Natura 2000 areas, the supervising european network sought that the biological corridor nature of the areas and the existence of the major species are adequately ensured. At the designation, there was no point, what is the role of the selected areas of in the nature conservation system of the given country: whether there are protected areas or just are suitable to serve the conservation of biodiversity because of the extensive farming? The organizations involved in the designation designated state and non-state areas to Natura 2000 areas the same as where the additional obligation of the user was the the maintenance of the area's current protection level and to insurance of 
the framework of land use. ${ }^{23}$ The land users were far less limited in the use of these areas than users of natural areas supervised by specific authorities decisions and management controls. Related to the monitoring of the use of Natura 2000 areas, the paying agency (Agricultural and Rural Development Agency) and later its legal successors (the agricultural and rural developments departments of government offices) included the national park directorates responsible for nature conservation tasks in the concrete verification of the use of area. The basic conditions of land use obligations were the farming activity and the fulfilment of special restrictions for a limited time, typically for the end of support cycle.

Related to the supervision, the authorities examined the legitimacy of the support and dealed with the support and delegated tasks absolutely did not take account of the question, whether the owner was a state authority, a natural person or a legal person. The special requirements of biodiversity ${ }^{24}$ were borne by current user and he could require the state support to the areas used by him. The owner was not financially interested in that the leaseholders meet the requirements provided for the special conditions of the support or not on the areas leased by the owner.

\footnotetext{
23 See: Tilki Katalin: A természetvédelem magyarországi helyzete és jogi környezete, a Natura 2000 hálózat, Belügyi Szemle, 2017/9, 72-88.; The obligation of competence and jurisdiction Member States' authorities is to make a proposal to the European Committee related to the requalification of nature area listed on the list of community important nature area in the case, if the owner of area belongs to the this nature area gave an application to the aforementioned authorities referring to the natural degradation of this area, if this application is based on the circumstance that the mentioned nature area, despite of the respect of this modified directive Article 6 (2)-(4), is permanently unable to contribute to the protection of natural habitats, wild animals and plants and the formation of Natura 2000 system: C-301/12 Közigazgatási-gazdasági döntvénytár, 2016/3, 54-59.; For the cancellation of application on the compensation support of Natura 2000 area financed from European Agricultural and Rural Decelopment Fund, the rules of European Community directives, which take precedence in their application and scope, shall be applied, because the Member States' regulations impose more serious obligations to the applicant: Curia Kfv. IV. 35 403/2013, Közigągatási-Gazdasági Döntvénytár, 2015/3, 5-7.; Mertens Cordula: Playing at multiple levels in biodiversity governance: The case of Hungarian ENGOs in Natura 2000, Society and Economy, 2013/2, 187-208.; Cseke Hajnalka: Zöld a pácban - Az Audi és a Natura 2000, Figyeló, 2011/30, 10-11.

${ }^{24}$ See about biodiversity: Kis József - Barta Sándor - Elekes Lajos - Engi László - Fegyver Tibor - Kecskeméti József - Lajkó Levente - Szabó János: A pásztorok tudásának és világnézetének szerepe a biodiverzitás és az ökoszisztéma-szolgáltatások fenntartásában, Természetvédelmi Közlemények, 2016/22, 96-111.; Némethy Sándor - Walas Bartłomiej: Bioenergy Crops as New Components of Rural and Agricultural Landscapes: Environmental and Social Impact, Biodiversity, Cultural Heritage and Economy: Bioenergia termények, mint a vidéki és mezőgazdasági kultúrtájak új komponensei: környezeti és társadalmi hatás, biodiverzitás, kulturális örökség és gazdaságosság, Journal of central European green innovation, 2015, 111124.; Puskásné Jancsovszka Paulina: A KAP „zöld komponense” és a biodiverzitás, Lépések a fenntarthatóság felé, 2015/1, 12-13.; Gencsi Zoltán: Biodiverzitás és természetvédelem a magyar Alföldön, Erdészeti Lapok, 2011/12, 374-375.
} 
This is a different situation, if in case of these areas the land ownership and the land use are merged in the hands of the owner, because in this case the special use obligations provided for the conditions of the support requirements will be borne by the owner. Because of this fact, in case of sale, it is important to take into account that the land user and the owner, who undertakes the commitments for it be aware of the fact that the preservation of a special rules of land use is not only a support requirement, but also the preservation of the national obligations of the sales state. ${ }^{25}$

So by the sale of the aforementioned-nature area, the land use of it will be restricted and the omission of which can result the loss of support and possible administrative sanctions too. In case of the general-nature sale of Natura 2000 areas not qualified as a nature conservation areas, the sales National Land Fund did not call the attention of the farmers applied for the area to meet the requirements and thus the National Land Fund committed a default, so to the remedying of it, the Constitutional Court found the infringement constitutional violation of the system of regulation. The Constitutional Court provided a deadline until 30 June 2018 for the adoption of special rules of the regulation of the aforementioned areas, but due to the fact that Natura 2000 areas are not part of the hungarian nature conservation system, the Constitutional Court rejected the initiative based on the petition.

Resulting from the serious work of referring Marcell $S_{z a b o^{26}}$ constitutional court judge, the Constitutional Court has made a decision, which is exemplary in the aspect of nature conservation and environmental law and which may be the basic of legal researches related to the Natura 2000 areas. Related to this decision, the different regulatory object and the regulatory method of domestic and European nature conservation law can be interpreted well in the field of nature conservation. While the domestic nature conservation law is based on the territories protection and species protection systems, the european nature conservation law is based on a systemic nature regulation similar to environmental protection, and a strange overlapping of these systems is the Natura 2000 areas, which are well identified with the concept of biological corridor regulated in the nature conservation act and explained in the previous part of this article. The Constitutional Court has interpreted strictly the action obligations created in the system of domestic environmental law related to nature conservation areas. It has only the responsibility for the state management and taking state ownership of nature conservation areas, the prohibition of regression only applies to the regulation system of these areas, the Natura 2000 area is not a nature conservation area guaranteed by the Fundamental Law of Hungary.

\footnotetext{
25 See Constitutional Court Decision no. 28/2017 (X.25) Points 15-18.: Several international legal instructions are analised by the Constitutional Court.

${ }^{26}$ Szabó Marcell: Az európai jog és a nemzetközi jogrend - hierarchia és összefonódás, Alllam-és Jogtudomány, 2012/2-3, 191-211.; Szabó Marcell: The Implementation of the Judgment of the ICJ in the Gabcikovo-Nagymaros dispute, Iustum Aequum Salutare, 2009/1; 15-26.
} 
The Hungarian nature conservation law creates a transition between the nature conservation areas and free arable areas. However for the special treatment of such areas, the state has a special obligation related to the requirements in connection with the fulfilment of the relevant European Union directives. This obligation is clearly defined as the system of the requirements of the special rural development supports related to the Natura 2000 areas. However the compliance of these requirements is embodied for the state in legislative obligation, having regard to the obligations related to the proper transposition of the Birds Directive 79/409/EEC and the Habitats Directive 43/92/EEC. Here the special situation derives from the fact that the new natural person owner becomes the individual user of the area at the same time. Since these two legally regulated status merged in one hand, so special rules shall be created to the legal compliance of special requirements. In my opinion, by the end of "Land for Farms" programme this new instruction system is qualified as a subsequent regulation and if the land use of unlimited land use owner is got heavy related to these obligations, resulting from the subsequent-nature of the regulation, it may also raise the possibility of the enforcement of the damage caused by contract. The other possibility is that due to the constraints of the circumstances, the owner, by the withdrawal from the contract, may require the repossession of the area by the state.

However in this case, the establishing of the payable compensation amount shall be based on the adequate compensation of the injured party, not on the actual value of the area.

In summary, the protected areas are owned by the state and the related special asset management and the ambition for the protection of this can be considered as an acquisition of the hungarian nature conservation law which has been the part of the hungarian legal system since 23 years and for the protection of it, different from other established institution, ${ }^{27}$ the Constitutional Court consistently applies the prohibition of regression related to the determination of legislative freedom of the state bodies.

\footnotetext{
${ }^{27}$ By the termination of Parliamentary Commissioner for Future Generations and the significant decrease of the official apparatus and budget of the deputy ombudsman responsible for the area, a retrocession happened at the significant and institutionalized area of environmental protection. This fact was not observed by the Constitutional Court ex officio (the opinion of the author).
} 


\section{OLAJOS István* \\ A természeti védettség alatt álló területek speciális kezelői joga, és a visszalépés tilalmának elve, valamint a tulajdonosi joggyakorlás jogának ütközése az állami tulajdonú területek kezelése kapcsán**}

\section{A természeti védettség alkotmányos alapjai}

A természeti védettség alatt álló állami területek problémái a szövetkezeti átmeneti törvény végrehajtása kapcsán jelentkeztek először a magyar jogban. A természetvédelmi jellegű szabályozás általánossá válásakor, és a Nemzeti Parkok rendszerének kialakítása kapcsán rögtön megjelent az az elv, hogy a területi védettséggel együtt, a nemzeti park igazgatóságoknak egy speciális kezelői joga keletkezik a Nemzeti Park lehatárolt területein. E területeken, a területi védettség elvét megfelelően érvényesítve, a terület használatában a természetvédelmi érdeknek lesz alárendelve a területhasználat. Ez a gyakorlatban azt jelentette, hogy például a Hortobágyi Nemzeti Park területén, ha egy mesterségesen létesített halastavon speciális, máshol nem pótolható ökoszisztéma jött létre, akkor természetvédelmi érdekből, a kisajátítási eljárás lefolytatása után, megtilthatóvá vált az ökoszisztéma védelmével össze nem egyeztethető intenzív halgazdálkodás. ${ }^{1}$

Mindez a folyamat a rendszerváltozásig (1991-es kárpótlási, ${ }^{2}$ szövetkezeti átalakulási, ${ }^{3}$ majd 1992-es szövetkezeti, valamint az 1993-as földkiadó és földrendező

István Olajos: The special asset management right of nature conservation areas, the principal of the prohibition of regression and the conflict with the ownership right in connection with the management of state-owned areas - A természeti védettség alatt álló területek speciális kezelői joga, és a visszalépés tilalmának elve, valamint a tulajdonosi joggyakorlás jogának ütközése az állami tulajdonú területek kezelése kapcsán. Journal of Agricultural and Environmental Law ISSN 1788-6171, 2018 Vol. XIII No. 25 pp. 157-189 doi: 10.21029/JAEL.2018.25.157

* PhD, egyetemi docens, Miskolci Egyetem Állam- és Jogtudományi Kar Civilisztikai Tudományok Intézete

** A tanulmány az Igazságügyi Minisztérium jogászkép zés színvonalának emelését célzó programjai keretében valósult meg.

${ }^{1}$ Lásd: A Hortobágyi Halgazdaság folyási kirendeltségének nemzeti parki törzsterületté való nyilvánításának folyamatát 1993-1996 között.

2 A kárpótlás, mint folyamat és annak jogi vetületének feldolgozásáról lásd: Kovács Csaba: Átalakítás vagy szétverés?: a szocialista jellegû mezőgazdaság végnapjai és a kárpótlás utáni gazdálkodás néhány sajátossága, Levéltári Közlemények, 2011/1, 239-260.; Gulácsy Katalin: A kártérítés, a kártalanítás és a kárpótlás adójogi megítélése, Adó, 2009/8, 15-18.; Menczer Gusztáv: A kárpótlás, mint jogintézmény, Gazdaság és Jog, 2005/4, 13-19.; Szirmai Márton: A magyar kárpótlás gyakorlati problémái, Tudományos kö̊lemények, 2000/2, 167.; Fertő Imre Mohácsi Kálmán: A politikai kárpótlás folyamata és következményei, Európa Fórum, 1996/2, 85106.

${ }^{3}$ A szövetkezeti átalakulás kapcsán lásd: Karner Ottó: Átalakulás és múködés (Szövetkezeti jogi praktikum), Gazdaság és Jog, 1998/2, 21-23.; Becz Miklós: A szövetkezeti átalakulás, Gazdálkodás, 
bizottságokról szóló törvények ${ }^{4}$ elfogadását értem alatta) viszonylag egyszerű folyamat volt, mert az állami és szövetkezeti tulajdon primátusára építő földtörvény jogi keretei között, ez a folyamat, mellyel az állami vagyonkezelés e természetvédelmi jellege érvényesült, egyszerű földcserével, a kisajátítás folyamatát mellőzve is megoldható volt.

A rendszerváltozás jogi alapjának számító kárpótlási, szövetkezeti átmeneti és az 1992-es szövetkezeti törvény folyamataiban csak másodlagosan érvényesült a természetvédelmi jellegú és nézőpontú szabályozás. A szabályozás lényege: a szövetkezeti tulajdon megszüntetése mellett egy kárpótlási, tagi-alkalmazotti, tagi és állami földalapba átirányítani a szövetkezeti földtulajdont. A földalapok kijelölése kapcsán a szövetkezet abszolút nem volt tekintettel saját megkötött szerződéseire sem, így több évre, ültetvénytelepítéssel terhelt, és más kizárólagos használatában álló területeket is kijelöltek akár kárpótlási földalapba. A földek használatának egyéb, például természeti védettséget garantáló korlátait nem vették figyelembe ennél a folyamatnál. ${ }^{5}$ Így kerülhettek addig természeti védettség alatt álló területek is úgy magántulajdonba, hogy a speciális földhasználatra vonatkozó kitétellel az új tulajdonos csak a későbbi, Nemzeti Park Igazgatóságok által meghozott, a tulajdonjogát korlátozó rendelkezésből értesült.

1994/1, 17-22.; Varga Gyula: A mezőgazdaság és a szövetkezetek átalakulása, Társadalmi Szemle, 1993/4, 32-41.; Váradi Monika Mária: Keskeny az ösvény. Esettanulmány a 'Harmónia' Mgtsz átalakulásáról, Replikea, 1998/33-34, 121-135.; Rácz Zoltán - Kenderes György - Tatár Irén Szilágyi Sándor: Mezögazdasági szövetkezetek átalakulási kézrikönyve, Miskolc, Regiocon, 1992, 227.

4 Államtitkári köszöntő a "Részarány földkiadás során keletkezett osztatlan közös tulajdon megszüntetése projekt tapasztalatai" konferencián, Geodéria és Kartográfia, 2015/11-12, 28.; Halász Imre László: Gondolatok és tapasztalatok a részarány földkiadás során keletkezett osztatlan közös tulajdon megszüntetésének eljárásáról, Geodézia és Kartográfia, 2006/11, 37-39. A földkiadó bizottságnak csak a törvényben meghatározott határozata minősül érdemi határozatnak, bíróság által csak ezek vizsgálhatók felül: 1993. évi II. tv. 6. \, 11. \(1) bek. a)-d) pont, KörigazgatásiGazdasági Döntvénytár, 1996/5, 71-72. A földkiadó bizottságok a törvény által meghatározott körben hatóságként működnek: 1993. évi III. tv. 11. S, Közigazgatási-Gazdasági Döntvénytár, 1999/3, 5-7. A haszonbérlő vételi joga részarány-földalapba kijelölt ingatlannal szemben nem gyakorolható. A földkiadást elrendelő földkiadó bizottsági határozatot megsemmisítő határozat nem keletkeztet jóhiszeműen szerzett jogot: Legf. Bír. Kfv. VI. 28 309/1998, KörigazgatásiGazdasági Döntvénytár, 2004/4, 27-31.

${ }^{5}$ Lásd: az 1992. évi L. törvény 4. S-ának azon rendelkezését, hogy kárpótlási földalap céljaira természetvédelmi magterület és nemzetközi egyezményben természeti védettség alá kerülő terület kivételével természeti védettség alatt álló terület is kijelölhető. Ez a módosítás enyhítette az 1992. évi II. törvény - Ámt. és az ezzel paralel 1991. XXVI. Kpt. azon rendelkezéseit, amit a természeti védettség alatt álló területeket a nemzeti park igazgatóságok kezelésébe adta, és helyükbe állami csereföld biztosítását írta. 
A kétfajta földhasználat és a földhasználat alapjául szolgáló két szemléletmód összeütközését először az első ciklus Alkotmánybírósága észlelte, és értelmezte a visszalépés tilalmának elvét ${ }^{6}$ megalapozó 28/1994 (V.20.) határozatában. A határozat alapjául szolgáló kérelem azon rendelkezésén alapult, mely a megnövekedett kárpótlási igények kielégítésére kárpótlási földalapba immár természeti védettség alatt álló terület is kijelölhető. Itt a visszalépés egy addigi kialakult természetvédelmi szabályozással és gyakorlattal is tökéletesen ellentétes volt. A természetvédelmi szabályozás háttérbe szorult az egyre fokozottabban jelentkező kárpótlási igényekkel szemben, melyet a kormányzat hajlamos volt elfogadni. A földterületek természetvédelmi kezelése azonban már az 1970-es évektől kezdve a magyar jogrendszer része volt. Környezetvédelmi szabályozásunk megszületésénél az Alkotmánybíróság akkori elnöke, Sólyom László ${ }^{7}$ bábáskodott, aki saját jogalkotói gyakorlatából észlelte milyen nehéz volt kialakítani természetvédelmi szemlélet érvényesülését a földek használata során. A nemzeti parkok speciális vagyonkezelési jogát olyan értéknek tekintette, mely megőrzendő értéknek minősült és a magyar környezetvédelmi szabályozás egy fontos, intézményi jellegében is egyedi szabályozásának volt tekinthető. A már említett 28/1994. (V.20.) AB határozat az egészséges környezethez való jogot nem csupán alanyi alapjognak, hanem „önállósult és önmagába vett intézményvédelem”-nek tekintette. Ennek kapcsán az állam környezetvédelmi kötelezettségeinek teljesítését és

\footnotetext{
6 A visszalépés tilalmának értelmezéséről lásd: Fodor László: A visszalépés tilalmának értelmezése a környezetvédelmi szabályozás körében, Collectio Iuridica Universitatis Debreceniensis, 2006/6, 109-131.; Halmos Gergő: Ne legyen visszalépés!, Madártávlat, 2015/2, 3.; Bándi Gyula: Környezeti értékek, valamint a visszalépés tilalmának értelmezése, Iustum Aequum Salutare, 2017/2, 159-181.; Csák Csilla: Környezetjog, Miskolc, Novotni Kiadó, 2009.; valamint a terület teljes monografikus értékéléséről lásd: Fodor László: Környezetvédelem az alkotmányban, Debrecen, Gondolat Kiadó, 2006, 106-163.

${ }^{7}$ Sólyom László környezetjogi jellegú írásai a következők: Sólyom László: The Rights of Future Generations, and Representing them in the Present, Acta Juridica Hungarica, 2002/1-2, 135-143.; Sólyom László: A jövő nemzedékek jogai és ezek képviselete a jelenben, in: Jávor Benedek (szerk.): A jövő nemzedékeke jogai, Budapest, Védegylet, 2000, 37-46.; Sólyom László - Szabó Máté (szerk.): A Zöld Hullám: Olvasókönyv a környezetvédelmi társadalmi mozgalmakról, Budapest, ELTE, 1988, 282; Sólyom László: A környezeti kockázatok elosztásának néhány előkérdése, Jogtudományi Közlöny, 1987/5, 221-226.; Sólyom László: Hans Engelhardt: Bürger und Umwelt, Jogtudományi Közlöny, 1986/10, 510-511.; Sólyom László: A társadalom részvétele a környezetvédelemben, Medvetánc, 1985/5-6, 217-242. Sólyom László: A polgári jogi bíróságok környezetvédelmi ítélkezése és a polgári jog lehetőségei a környezetvédelemben, in: Trócsányi László (szerk.): Körmyezetvédelem és a jog, Budapest, Akadémiai Kiadó, 1981, 148-179.; Sólyom László: Der zivilrechtliche Umweltschutz und die Möglichkeit einer Bürgerklage im ungarischen Recht, Acta Juridica Academiae Scientiarum Hungaricae, 1980/1-2,19-55.; Sólyom László: Környezetvédelem és polgári jog, Budapest, Akadémiai Kiadó, 1980; Sólyom László: Egy környezetvédelmi populáris akció elvi lehetősége polgári jogunkban, Jogtudományi Közlöny, 1978/11, 672-682.; Sólyom László: Biztosítás és egyéb technikák a környezeti károk fedezésére Állam-és Jogtudomány, 1978/3, 306-338.
} 
ennek garanciáit az alapjogok szintjére emelte. ${ }^{8}$ „A természetvédelem jogszabályi biztosított szintjét az állam nem csökkentheti, kivéve, ha ez más alkotmányjog vagy érték érvényesítéséhez elkerülhetetlen. A védelmi szint csökkenése az elérni kívánt célhoz képest ekkor sem lehet aránytalan."9 Így fogalmazta meg az Alkotmánybíróság a visszalépés tilalmának elvét, mely azóta is töretlenül érvényesül az Alkotmánybíróság joggyakorlatában, és az állam környezetvédelemmel kapcsolatos tevékenységének egyik legnagyobb korlátját jelenti. Ez a jog később kiterjedt az épített környezet védelmére (27/1995. (V.15.) AB határozat), ez jelentette a tulajdonjog környezetvédelmi okból való, jelentős mértékű korlátozásának a lehetőségét is (64/1993. (XII.22.) AB határozat). ${ }^{10}$ Ebből az elvből vezethető le az is, hogy a környezetvédelmi érdek nem rendelhető alá területfejlesztési érdeknek: a gazdaság fejlesztése és a környezeti érdek közötti egyensúly fenntartása a fontos.

Az Alkotmánybíróság saját szerepének átértelmezését igényelte az elfogadott Alaptörvény megváltozott szövege. Ahol az Alaptörvény enyhítette az állam alapjogokért való felelősségét, ott a bírák nem tartották magukat elődjeik szigorúbb jogértelmezéséhez. Mivel azonban a környezet védelme a Nemzeti Hitvalláson túl az Alaptörvény P) cikkében és a XXI. cikkében is megjelenik, összességében az Alkotmánytól erősebb tartalommal, így e jogterület kapcsán 3068/2013. (VI.17.) AB határozatában az Alkotmánybíróság megállapítja, hogy az eddigi határozatokat magára nézve kötelezőnek ismeri el. Ez abból vezethető le, hogy „az Alkotmányhoz képest az Alaptörvény e tárgykörben lényegesen bővebb rendelkezést tartalmaz, így az Alkotmány továbbfejlesztésének tekinthető."11

\section{Alapintézménynek tekinthető-e a nemzeti parkok speciális kezelői joga?}

A kérdés legközelebb a 16/2015. (VI.5.) AB határozat kapcsán merült fel, melyben az a kérdés került az Alkotmánybíróság elé, hogy a védett területek tekintetében a 2015. évi CCIV. törvény, mely az állami földvagyon kezelésével összefüggő egyes törvények módosításáról szól (a továbbiakban: Módtv.), meghozatalával van-e joga a jogalkotónak természeti védettség alatt álló területet vagyonkezelői jogának átruházására a Nemzeti Földalap részére.

A természetvédelmi vagyonkezelés szabályait jelenleg a 262/2010 (XI.17.) kormányrendelet (továbbiakban Nfavhr) 43/A és 43/B \-ai a következóképpen szabályozzák:

„A természetvédelmi célú vagyonkezelés elsödleges célja állami tulajdonban álló földrészleteken természetvédelmi közcélok megvalósitása, az élö és élettelen természeti értékele megóvása, a tájképi, kultuirtörténeti értékele megórzése, a természeti vagyon állagának és értékének megörzése, védelme, továbbá értékének. fenntartható módon való növelése.

\footnotetext{
8 28/1994. (V.20.) AB határozat 134. és 138., valamint Sulyok Katalin: Az Alkotmánybíróság előzetes normakontroll döntése a nemzeti park igazgatóságok vagyonkezelői jogkörének csorbítása tárgyában.

9 28/1994. (V.20.) AB határozat 141.

${ }^{10}$ Sulyok 2015, 19.

${ }^{11}$ Sulyok 2015, 19.
} 
A természetvédelmi célú vagyonkezelés során a védett területen történö mezoó", erdögazdálkodási tevékenység (a továbbiakban: gazdálkodás) a természetvédelmi célokra tekintettel folytatható, elönyben kell részesiteni a hagyományos (tájjellegü), természetkiméló, természetteözuli gazdálkodási módok alkalmazását, biztositani kell az öshonos és régen honosult háziállatok állományának génrezervátumként való fenntartását, valamint az állatállományok (megfeleló létszám, faj- és fajtaösszetétel esetén) útján a védett terület természetvédelmi érdekeknek megfeleló területfenntartását, gondozását.

A nemzeti park igazgatóság (a továbbiakban: igazgatóság) a vagyonkezelésben lévö védett területek nyilvántartását a Természetvédelmi Információs Rendszerben naprakészen vezeti.

Az. igazgatóság a vagyonkezzlési tevékenységét a természetvédelemért felelós miniszter által jóváhagyott hosszútávú (10 éves) természetvédelmi célú vagyonkezelési terv, valamint az annak alapján elkészitett éves természetvédelmi célú vagyonkezelési terv figyelembevételével végzi.

Az igazgatóság a vagyonkezelésében álló vagy vagyonkezelésébe kerüló védett területet érintöen a birtoklás, a has₹nálat, és has₹nositás jogát saját maga gyakorolja (a továbbiakban: saját használat), ba

(a) a védett terület klimax és abhoz. közeli állapotú társulások.kal boritott természetvédelmi oltalom alatt álló terület, amelyen a természetvédelmi szempontok - a kiemelkedö jelentöségü, értékü védett természeti terïletek és értékek - miatt gazdálkodási tevékenység nem lehetséges; vagy amelyek nem igényelnek természetvédelmi fenntartási tevékenységet, ezért a védett terület hasznositása tilos, vagy igen nagymértékben korlátozott (igy különösen egyes biosaféra-rez̧ervátum magterületek, tudományos rezervátumok, egyes természeti övezetbe tartozó területek, egyes fokozottan védett természeti területek);

(b) a védett területen a természetvédelmi érdekek érvényesitése speciális tevékenység végzését, vagy különleges szakismeret, esetleg eszköz. meglétét kivánja meg, és ezek nélkül a védett terület használatba adása elóreláthatólag a természeti értékelk károsodásával, szaporodásuk veszélyezutetésével, vagy pusztulásával járna;

(c) ha a védett területen a természetvédelmi célkitüzések az igazgatóság rendelkezésére álló vagy reálisan megszerezhetô" eszközö̈kkel és személyi állománnyal - az. igazgatóság többi állami feladatának ellátásával összhangban - racionálisan megvalósithatók, valamint elengedhetetlenül szüleségesek az igazgatóság tulajdonában, vagyonkezelésében, valamint használatában lévó állatállomány fenntartásáboz, ellátásáboz;

(d) a védett terület az. ingatlan-nyilvántartás szerint erdö müvelési ágban van nyilvántartva, vagy ennek hiányában, amelyre az ingatlan-nyilvántartásban az Országos Erdöállomány Adattárban erdöként nyilvántartott védett terület jogi jelleg ténye van feljegyezue, és az. Országos Erdöállomány Adattárban foglaltak szerint elsödlegesen gazdasági rendeltetésü erdönek minösül, vagy

(e) a védett terïleten a természetvédelmi hatóság a hasznositási kötelezettséget felfüggesżtette."

Elemezve a fenti szakaszokat: a vagyonkezelés történhet úgy, hogy a vagyonkezeléssel megbízott igazgatóság az állami tulajdonú területet másnak haszonbérbe adja, illetve úgy is, hogy saját eszközeivel ezt racionálisan meg tudja oldani az igazgatóság, ha a terület speciális védelem van feljegyezve, ha a terület erdő, vagy a védett területen a más gazdálkodó számára előírt hasznosítási kötelezettséget, annak nem megfelelő volta miatt, felfüggesztette. 
A Módtv. 1-6. \-ai szerint a természeti területek speciális vagyonkezelői joga megszúnik, és az általános szabályok szerint a Nemzeti Földalap gyakorolhatott volna vagyonkezelői jogot, és a 8. \ alapján elővásárlási jogot is az ilyen területeken. A többi területen a vagyonkezelői jog csak olyan területekre korlátozódott volna, amelyek a nemzeti park igazgatóságok alapfeladatainak ellátásához közvetlenül kapcsolódnak vagy alapító okiratukban, illetve alapszabályukban közvetlenül szerepelnek. ${ }^{12}$

Értelmezve ezt a rendelkezést, a Nemzeti Földalap nem kap természetvédelmi jellegű vagyonkezelői jogot, ez az intézmény megszűnik, és beleolvad a Nemzeti Földalapot korábban is megillető általános vagyonkezelői jogba. Ez a megállapítás azért nem helytálló tökéletesen, mert az általános vagyonkezelői jog kibővül egy elővásárlási jogosultsággal, és a természetvédelmi magterületeken, illetve feladataik ellátása kapcsán megmarad a nemzeti parkoknál. A nemzeti park tehát, ha e szabályozás hatályba lépett volna, természetvédelmi jellegű szabályozó és korlátozó tevékenységét csak a természeti védettség legmagasabb szintjén álló területeken gyakorolhatta volna, és nem lett volna joga arra, hogy a természeti környezet változását figyelemmel kísérve természeti védettséget más tulajdonában álló vagy más vagyonkezelésében lévő területekre is kiterjessze. Terjeszkedési lehetőségei tehát erősen behatároltak lennének. A szabályozás nemcsak jogi kereteit vesztené el, de legalábbis minimálisra szűkítené, hanem megdőlne az 1999-es kidolgozása óta az agrár-környezetvédelem egyik alapjának tekintett, a földhasználati piramis elvén kidolgozott földhasználati zónarendszer is. ${ }^{13}$

A zónarendszer tudományos alapjaként Magyarország földjei egyszerre esnek át egy agrárgazdasági használatot megalapozó agrár- és a természeti védettségi szintjüket meghatározó környezetvédelmi minősítésen. Az olyan területek, amelyek gazdálkodási

12 16/2015. (VI.5.) AB. hat. 4-9.

13 Ángyán József - Podmaniczky László - Ónodi Gábor: Agrár-környezetgazdálkodás és vidékfejlesztés: az európai agrárfinanszírozás új útja a gyakorló gazda szemszögéből, Falu Város Régió, 2003/8, 3-12.; Pálvölgyi Kálmán: Mit tehet az agrár-környezetgazdálkodásban (AKG) résztvevő gazdálkodó, ha nem tudja, vagy nem akarja vállalni a szerződésben foglalt kötelezettségeit?, Agrárágazat, 2006/8, 8-9.; Dömsödi János: A földértékelés, földminősítés módszertani elemzése, rendszerezése, továbbfejlesztése, Geodézia és Kartográfia, 2007/3, 26-33.; Szilágyi János Ede: Common Agricultural Policy, new rules of WTO and regional equilibrium, Journal of Agricultural and Environmental Law (JAEL), 2008/5, 3-18.; Farkas Csamangó Erika: Az agrár-környezetgazdálkodás alapjai, Acta Universitatis Szegediensis: Acta juridica et politica, 2008/1-17, 151-182.; Gyarmati Ágnes: Az agrár-környezetgazdálkodás támogatása a Nemzeti Vidékfejlesztési Terv bevezetése kapcsán, Acta Agraria Debreceniensis, 2006/20, 52-59.; Csák Csilla - Olajos István: The application of the single payment by national administrations and national courts, JAEL, 2008/5, 31-42.; Szilágyi János Ede: Magyar Nemzeti Jelentés a gazdálkodók tevékenységének diverzifikációját érintő jogi ösztönzőkről és jogi akadályokról, JAEL, 2010/8, 3-48.; Horváth Gergely: Gondnokság - Az agrár-környezetjog funkciója és felépítése, Jog, Allam, Politika, 2012/2, 107-127.; Csák Csilla: Cross compliance, avagy környezetvédelem a támogatás feltételeként, Publicationes Universitatis Miskolcinensis. Sectio Juridica et Politica, 2012/2, 423-433.; Csák Csilla:A fenntartható természeti erőforrás-gazdálkodás jogi szabályozása, Müszaki földtudományi közlemények, 2013/2; 73-86.; Marticsek József - Molnár Dániel - Mozsgai Katalin - Podmaniczky László - Skutai Julianna - Tóth Péter: Az agrárkörnyezetgazdálkodási támogatási rendszer fejlesztési lehetőségei (Hogyan tovább agrárkörnyezetgazdálkodás?), Természetvédelmi Közlemények, 2015, 21. kötet, 232-242. 
szempontok mellett természetvédelmi szempontból is jelentősnek minősülnek, a jelenlegi besorolás szerint további támogatást igényelhetnek azért, hogy természetvédelmileg jelentős jellegük megmaradjon. E területeken a termelés és az ehhez kapcsolódó agrár-alaptámogatások mellett agrár-környezetgazdálkodási vagy Natura 2000 alapú támogatások is igényelhetők, melyek feltétele a termelés folytatása mellett a speciális területre jellemző környezetvédelmi tevékenység átvállalása az államtól. Itt tehát a termelő saját termelésének korlátozása mellett állami környezetvédelmi feladatokat vállal át, állami környezetvédelmi feladatokat végez, és a környezetvédelmi tevékenység költségeinek fedezésére jár a Vidékfejlesztési Operatív Program részeként e speciális támogatás. ${ }^{14}$ A feladatellátás tényleges ellenőrzését és a változó környezetnek megfelelően a kapcsolódó termelői kötelezettség erősödését vagy gyengülését a nemzeti park igazgatóságok határoztak meg és ellenőrizték. Ha a termelő az egyre szigorodó környezetvédelmi előírásoknak már nem tudott eleget tenni, kérhette a védettségi szint helyreállításáról szóló 1995. évi XCIII. törvény (a továbbiakban: Vszt.) rendelkezései alapján területének kisajátítását, és a kártalanítási összeg felvétele után az adott területre, mint állami tulajdonra a nemzeti park igazgatóságok speciális vagyonkezelői joga került bejegyzésre.

Ezt tehát csak a területhasználó és a kisajátítást kérő, illetve annak anyagi fedezetével is rendelkező nemzeti park igazgatóságok konszenzusa alapján lehetett kezdeményezni a teljes, azonnali és feltétlen kártalanítási összeg megfizetése után. A kisajátítások mértékét mindig természetvédelmi célra rendelkezésre álló költségvetési források határozták meg. ${ }^{15}$ A kisajátítás kezdeményezésének ezen lehetősége szűnt volna meg a Módtv. elfogadása kapcsán, és került volna a defenzív állami földpolitikát folytató (lsd. Földet a gazdáknak program) Nemzeti Földalap hatáskörébe. E lehetőség nem eredményezte volna az állam tulajdonának további bővülését, viszont a természetvédelem szerepének további csökkenésével járt volna együtt, ugyanis az önálló minisztériumi struktúráját elvesztő nemzeti park igazgatóságok feladat meghatározó, ellenőrző funkciója is csökken és a természetvédelmi jellegű vagyonkezelés lehetősége kizárólag a magterületekre korlátozódik.

\footnotetext{
${ }^{14}$ Hegyes Péter: Links Between Rural Development and Direct Payments Based on the "CAP Reform” of 2013, Agrár-és Környezetjog, 2014/17, 39-49.; Andréka Tamás - Bányai Krisztina Olajos István: The most changes of the Hungarian Agricultural Market Policy after the 2013th CAP reform, JAEL, 2015/19, 6-18.; Gyurán Ildikó - Olajos István: Magyar Nemzeti Jelentés Földhasználat és földvédelem a tagállamok jogában, JAEL, 2012/12, 79.; Olajos István: The provisions of the Rural Development in connection with the agriculture in Hungary, Agrár-és Környezetjog, 2006/1, 3.

15 Andorkó Imre: A kisajátítás a tulajdonjog korlátainak rendszerében, Iustum Aequum Salutare, 2013/2, 241-253.; Horváth Paula: Néhány gondolat a kényszeradásvétel (kisajátítás) tervbe vett új szabályozásához, Magyar Köæigazgatás, 2005/2, 121-124.; Kampis György: A kisajátitás jogi rendezése és az új Ptk., Gazdaság és Jog, 2001/4, 18-21.; Prugberger Tamás: Adalékok a kisajátítás jogintézményének a korszerűsítéséhez, Magyar Közigazgatás, 1991/2, 176-180.
} 


\section{Az NFA általános vagyonkezelöi jogának gyakorlása-és a haszonbérlői pozícióban történő speciális joggyakorlás dilemmái}

A szabályozás másik nagy problémája az, hogy a vagyonkezelői jog általános jellege a vagyonhasznosítás körében nem tartalmaz természetvédelmi szempontokat és ezzel nem bővül a Nemzeti Földalap feladat- és hatásköre. Tehát, ha egy terület természetvédelmi értéke a jövőben megnő, a földhasználat további szigorítására lenne szükség, azt a természetvédelmi vagyonkezelói jogát elvesztó nemzeti park hálózat már nem képes megtenni és szintén nem teheti meg a természetvédelmi jellegú feladat- és hatáskörrel nem rendelkező Nemzeti Földalap sem. Tehát a módosítás nem értelmezhető úgy, ahogy Varga Zs. András alkotmánybíró különvéleményében kifejti16, hogy itt nem történik más, mint az egyik állami szervtől (nemzeti park igazgatóságok) egy másik állami szervhez (Nemzeti Földalap) kerülnek át jogosultságok és hatáskörök.

Szigorúan értelmezve tehát egyet kell értenünk azzal, hogy a jogszabályváltozás következtében elnehezedik a természetvédelmi intézményrendszernek azon jogosultsága, hogy saját szempontjai alapján más személyek földhasználatát befolyásolni tudja. A földhasználóknak szúkül az a lehetősége, hogy bekapcsolódhasson az agrárkörnyezetgazdálkodási program Unió által finanszírozott gazdálkodási kereteibe. Ezáltal pedig a magyar agrár-környezetgazdálkodási támogatásokat igénybe vevők köre jelentősen csökkenne, ezáltal a Vidékfejlesztési Operatív Programban komoly pénzmaradványok keletkeznének. Ez a vidékfejlesztéshez kapcsolódó tervezés újraindításával járna, amelynek kifutása a 2020-ig rendelkezésre álló kétéves időszakban nehezen lenne befejezhető.

A Módtv. érintett szakaszai egy meglévő intézményi struktúrába avatkoztak be, vontak el hatáskört a természetvédelmi intézményrendszertől és adtak át hatásköröket az általános agrár-vagyonkezelést biztosító Földalapnak oly módon, amely által területi védettség és annak változó környezethez való változtatási lehetősége szűnt volna meg. Az általános vagyonkezelói jog a fent elemzett természetvédelmi vagyonkezeléshez képest sokkal szúkebb hatáskör. Az állami joggyakorló az NFA tv. alapján, itt is élhet speciális, csak számára meghirdetett többletjogokkal és ezért ennek gyakorlása kapcsán a vele szerződő félnek is speciális többletlehetôségeket biztosít. A Földforgalmi törvény elfogadása előtt állami földek tekintetében az államnak joga volt földekre vonatkozó haszonbérleti szerződésben piaci haszonbérleti díjaktól lényegesen kedvezményesebb haszonbérleti díj ellenében használatba adni állami tulajdonban álló földeket egy arra kiválasztott személyi körnek. E haszonbérleti szerződés, mivel az ellentételezés lényegesen kevesebb volt, mint a haszonbérleti dij, inkább rövidtávú, néhány éves szerződésnek volt tekinthető, és az állam nevében eljáró, a földhasznositás jogát gyakorló Nemzeti Földalap kiköthette, hogy joga van a szerződés fennálló tartama alatt kétévente módosítani a bérleti díj összegét. ${ }^{17}$

16 16/2015. (VI.5.) AB határozat, 215-218. pontjai.

${ }^{17}$ Lásd: Nfavhr., 36. \. 
A Földet a gazdáknak program elfogadása után az állami földvagyon hasznosítására vonatkozó birtokpolitika megváltozott, az állam piaci áron értékesítette földvagyonának meghatározó részét, állami földárveréseken a legtöbbet ígérô földműves ajánlatát fogadták el, akinek lehetősége volt a vételárat kedvezményes, állam által dotált banki hitelekből is törleszteni. E banki hitelek azonban, tipikusan, még így is több törlesztő részletet igényeltek, mint amennyit az eddigi használótól haszonbérleti díj jogcímén kaphatott a megvásárolt föld új tulajdonosa. A pénzintézet, amely az ô földvételét hitelezte, természetesen az általa szolgáltatott kölcsön utáni hónapban már követelte a kamatot és a megfelelő törlesztő részletet attól a tulajdonostól, aki a fennálló bérleti szerződés miatt még évekig nem volt képes banki hitel feltételeként meghatározott, üzleti tervében foglalt gazdálkodási tevékenység folytatására. Mit tehetett tehát a megvásárolt földrészlet tulajdonosa? Mivel a Nemzeti Földalap helyébe lépett, és mint haszonbérbeadó az ő jogait gyakorolta, joga volt megváltoztatni a haszonbérlője által fizetendő haszonbérleti díjat. A haszonbérleti díj ezért akár tízszeresére is emelkedhetett, és ennél nagyobb egyoldalú használatidíj-változás sem volt egyedülálló ebben az időszakban. Az új tulajdonosnak ugyanis abszolút nem volt érdeke a használati szerződés fenntartása, és a megörökölt szerződés által biztosított többletlehetőségeit kihasználva arra szerette volna kényszeríteni az általa megörökölt földhasználót, hogy hagyjon fel ezirányú tevékenységével. ${ }^{18}$ Nyilvánvaló, hogy többéves profitorientált földhasználati előzmények után sem lehet egy meghatározott területen tízszeres földhasználati díjat kigazdálkodni, így a fizetésképtelenné váló földhasználó kénytelen felhagyni a földhasználattal, mert ha földhasználati díj tartozása halmozódik fel, a Földforgalmi törvény vonatkozó szakaszainak ${ }^{19}$ megfelelő értelmezése alapján nemcsak újabb területek haszonbérlőjeként nem léphet fel, de kizárt az, hogy mező- és erdőgazdálkodású földek tulajdonjogát megszerezze. A földhasználónak két lehetősége maradt: élve a közös megegyezés lehetőségével önmaga kezdeményezi a fennálló földhasználati szerződése megszüntetését vagy pedig polgári pert indít a „clausula rebus sic stantibus"-ra hivatkozva azért, hogy polgári peres bíróság állapítsa meg a szerződés tényleges tartalmát közte és az új tulajdonos között. A tartalom megállapításában fontos szerepe lehet annak, hogy abban az időszakban, amikor a jogutódlás megtörtént, a szerződésben szereplő egyik fél sem volt olyan, amely a Nemzeti Földalapról szóló törvényre hivatkozva speciális többletjogokkkal rendelkezett, és mint ilyen az NFA tv. szerinti haszonbérleti szerződés kötésére jogosult lett volna. A haszonbérleti szerződés ugyanis a Földforgalmi törvény használati szabályairól szóló, szabályait tartalmazó 38. \$a alapján bár szerepel a bevett szerződési jogcímek között, de az állami haszonbérbe adó speciális többletjogait a felek jogviszonyára nem lehet alkalmazni. Így folytatva a felperesi érvelést, csak a Földforgalmi törvény által szabályozott haszonbérleti, felesbérleti, részesművelési szerződést és az abban meghatározott, Földforgalmi törvénybe illeszkedő szerződési kikötéseket hozhatott volna létre a bíróság.

\footnotetext{
${ }_{18} \mathrm{Az}$ Nfavhr. 36. \ második fordulata alapján, ha a felek a megemelt haszonbérleti díjban nem tudnak megállapodni a haszonbérbe adó a szerződést felbonthatja.

${ }^{19}$ Lásd: Fftv. 14. \$.
} 
Az egyik ilyen fontos kikötés, hogy használati szerződés használati diját a szerződő felek csak öt év elteltével módosíthatják ${ }^{20}$ és ez minden, a Földforgalmi törvény hatálya alatt megkötött szerződésre vonatkozik. Tehát, ha a bíróság kimondja, hogy az alanyváltozás miatt az Nfavhr. szerinti haszonbérleti szerződés nem, csak a Fétv. szerinti haszonbérleti szerződést köthetnek a felek, arra mint általános jogszabályba ütközőre a szerződés azon kitétele, hogy kétévente egyoldalúan megváltoztatható a haszonbérleti díj összege, és az ilyen jellegű szerződésmódosításhoz a mezőgazdasági igazgatási szerv hozzájárulása szükséges, amely jelen esetben szintén nem volt meg.

A harmadik lehetőség, hogy az Alaptörvényben biztosított szerződési szabadság, az ügyek méltányos elbírálásához való jog, s a szerzett jogok sérelmének elve alapján az állammal szerződést kötő nem kerülhet olyan helyzetbe, mely az ô megszerzett jogainak sérelmével jár. Ebben az esetben tehát az adott ügyben felmerülő panaszt az eljáró bíróság általános jogelvek sérelmét feltételezve az Alkotmánybíróság előtt is megtámadhatja. Erre került sor 2017 novemberében, amikor az Alkotmánybíróság a hasonló tárgyban elé került alkotmányjogi panaszt elutasította.

A 27/2017. (X.25.) AB határozat teljesen más alapon, a sarkalatos törvényekhez kapcsolódó állami vagyon kiüresítése kapcsán támadja a „Földet a gazdáknak!” címú programot. A program egyik legfontosabb eleme, hogy az állam értékesíti földvagyonának mezőgazdaságilag hasznosítható vagyonrészét úgy, hogy a Földforgalmi törvény preambulumában meghatározott földművesek kezelésébe kerüljön. E tekintetben az állam meghatározott elvek szerint működő birtokpolitikájának végrehajtása kapcsán pénzért megszabadul az egyéb módon tulajdonába került földrészletek jelentős részétől. A program kapcsán a földtulajdon és a földhasználat egységesítésére törekszik, és elősegíti a Földforgalmi törvény nyilatkozati rendszerével kialakított azon tény érvényesülését, hogy csak az szerezhessen tulajdonul mező- és erdőgazdasági földet, aki annak sajátjakénti művelésére kész és képes. Az indítványozó a jogalkotási kérdések mellett azt sérelmezi, hogy a program működésével kiüresítik az Alaptörvény $\mathrm{P}$ ) cikkét azáltal, hogy az állami tulajdonos értékesíti a tulajdonában álló termőföldeket. Ezáltal nem lesz tulajdonosi beleszólása abba, hogy a nemzet közös öröksége a jövő nemzedéke számára megőrizhető legyen. Az Alkotmánybíróság értelmezésében termőföldek védelme azonban egy sokrétű szabályrendszer és nem kizárólag az állami tulajdon primátusának elve alapján őrizhető meg.

„A termőföldre vonatkozó szabályozás sokrétű: a termőföld védelmérôl szóló 2007. évi CXXIX. törvény határozza meg a termőföld mennyiségi védelmét, ez is független a tulajdonostól és egyetlen eleme sem sarkalatos. Az erdők az Alaptörvény P) cikkében kiemelt és nevesített védett jogi tárgy, azonban az erdőkről szóló 2009. évi XXXVII. törvény tartalmaz nem sarkalatos előírásokat, így e jogszabály ezen részei egyszerű többséggel is módosíthatók... A Földforgalmi törvény teljes egészében sarkalatos és nemcsak az állami tulajdonra vonatkozó részében, ez a jogszabály hajtja végre az Alaptörvény P) cikk (2) bekezdését. A természeti védettség alatt álló földek állami tulajdonban maradását a szintén nem sarkalatos 1996. évi LIII. törvény, a természetvédelmi törvény garantálja, amely a miniszter engedélyével teszi lehetővé az

${ }^{20}$ Fétv. 50/A. S. 
azonos természeti értékű védett természeti területtel történő földcserét, azonban az elidegenítés egyéb módjait nem engedélyezi."”21 Az Alkotmánybíróság természetvédelmi törvény kapcsolódó szakaszaihoz hasonló, az állami tulajdonban maradó földek védelmét biztosító jogintézményként értelmezi a védett természeti területek védettsége szintjének helyreállításáról szóló, e cikkben már elemzett 1995. évi XCIII. törvényt. E törvény mellett a védett természeti területek állami tulajdonban tartását szolgálja az elôvigyázatosság környezetjogban általános elfogadott elvének érvényesülése, mely értelmében az állam biztosítania kell azt, hogy a környezet állapotának a romlása egy adott intézkedés következtében ne következzen be. A „Földet a gazdáknak!” program érvényesítése kapcsán azonban elmondható, hogy a földkijelölés folyamatában következetesen érvényesítették a természetvédelmi törvény említett 68 . \ (8) bekezdésének előírásait, tehát közvetlen értékesítésre a természeti védettség alatt álló földekből nem került sor. Az indítvány második lényeges pontja volt, hogy mire költhetô a sarkalatos törvények által védett állami vagyon értékesítése kapcsán befolyt bevétel. Az indítványozó szerint ez a vagyon kizárólag a jövő generáció céljaira fordítható és nem szabadon felhasználható az állam mindenkori költségvetésének céljaira. Az Alkotmánybíróság e tekintetben vizsgálta a Nemzeti Földalapról szóló törvény ilyen jellegű előírásait. Megállapította, hogy a Nemzeti Földalapba tartozó földrészlet megterhelése, biztosítékul adása és osztott tulajdonba adása tilalmazott, azonban e tilalom nem vonatkozik a tulajdonjog átruházására, így azáltal, hogy megváltozik az állami tulajdonos e földrészletek tekintetében, kikerülnek a földek az állami vagyon köréből, és továbbiakban nem vonatkoznak rájuk a vagyonkezelés 38 . Sában említett tilalmai sem. Az állami tulajdonból kikerült vagyontárgy értékesítése továbbiakban sem teljesen szabad, ugyanis tárgya szerint termőföld, amire a Földforgalmi törvény személyi, tárgyi és megszerezhető területmennyiségben meghatározott korlátokat ír elő, így az értékesítés folyamatában ezen jogszabályok betartása mellett folyt és folytatható az értékesítés.

A megállapítással ellentétes különvéleményt fogalmaz meg Czine Agnes alkotmánybíró, mely alapján arra a következtetésre jut, hogy „a Nemzeti Földalap működése a termőföldek és erdők védelmével összefüggésben kiemelt fontosságú. Értelmezésében a Nemzeti Földalap ugyanakkor a rendeltetésének kizárólag akkor tud eleget tenni, ha az ehhez szükséges eszközök a rendelkezésére állnak. A „Földet a gazdáknak!” program keretében elvont 203 ezer hektár földterület kivonása olyan mértékű vagyonvesztés, mely nagymértékben érinti a Földalap működését, hogy csak és kizárólag sarkalatos törvénnyel hagyható jóvá az intézmény vagyonkezelési feladatainak kiüresítése. Az alkotmánybíró asszony értelmezésében termőföldvagyon helyébe lépó bevételt a Nemzeti Földalap céljainak megfelelően kellett volna felhasználni, mert az értékesítésből származó bevétel elvonása a Nemzeti Földalapban megmaradt termőföldvagyon megóvását és a jövő nemzedékek számára való megőrzését veszélyezteti. Ezért egyetértve az indítványozóval az alkotmánybíró asszony az ügylet kapcsán megállapíthatónak véli az Alaptörvény 38. cikk (1) bekezdésének, tehát a nemzeti vagyon kezelése és védelme céljainak megsértését.

${ }^{21}$ Lásd: 1996. évi LIII. törvény a természet védelméről (a továbbiakban: Tvt.), 68. $\int$ (8) bek. Az idézett szakasz a 27/2017. (X.25.) AB határozat 41. pontjából származik. 
Hasonló álláspontot alakít ki Stumpf István alkotmánybíró, aki úgy véli, hogy a nemzeti földvagyon értékesítése és az ebből származó bevétel az államadósság törlesztésére való fordítása megszünteti a nemzeti földvagyon különvagyon jellegét és azt, hogy az ebból származó bevételt kizárólag a nemzeti földvagyon speciális céljaira fordítsák. Az Alkotmánybíróság többségével elfogadott jogértelmezés Stumpf alkotmánybíró véleménye alapján megkérdőjelezi a P) cikk egész létének érvényesülését is.

Mint látható, az Alkotmánybíróság sem egységes abban, hogy a P) cikk védelmében milyen jellegű vagyonmegőrzési kötelezettséggel tartozik az állam. Az utóbbi két alkotmánybíró véleményéről egyértelműen elmondható, hogy a vagyontömeg-gazdálkodás kérdései értelmezésükben fontosabbnak tűnnek, mint az állami agrárpolitika érvényesülése, amely ténylegesen a tulajdon és a használat egységesítésére törekszik, és arra, hogy a földet ténylegesen használó és abból saját egzisztenciájukat, valamint az ország mezőgazdasági termelését biztosító földhasználók legyenek a termőföldek tulajdonosai.

Ez a cél véleményem szerint sokkal fontosabb, mint nagytömegű területek állami tulajdonban tartása, és az állami vagyonkezelés eszközeivel egy olyan földhasználói kör fenntartása, aki nyilvánvalóan más tulajdonán gazdálkodik. Véleményem szerint az előbbi állami cél felel meg a leginkább a Földforgalmi törvény preambulumában jelzett állami agrárpolitika végrehajtásának és ennek következetes alkalmazásával megőrizhető e stratégiai ágazat múködőképessége és az, hogy az erre vonatkozó szerzési szabályokat a jog eszközeivel lehessen irányítani és fenntartani, és ne közvetlenül az állami tulajdonosi döntés mindenkori politikailag befolyásolható eszközével legyenek irányíthatóak.

A jövő generáció érdekeit nem a nagymértékủ állami földtulajdon, hanem az egységesen kezelt magánföldtulajdon és - földhasználat biztosítja. Az állam akkor tudja megvédeni a jövő generációk érdekeit, ha a generációváltás kapcsán is alkot olyan szabályokat, amelyek ezen egység fenntartásához és a kialakított birtokszerkezet védelméhez járulnak hozzá. Konkrétan a föld öröklése kapcsán nem engedi a kialakított birtoktestek felosztását és a használható birtokszerkezet megbontását. Ehhez azonban nem állami földkezelő szervezetek fenntartása, hanem jól átgondolt és következetesen alkalmazott földöröklési rendszer érvényesítése szükséges. ${ }^{22}$

22 A mező és erdőgazdasági földek speciális öröklésének szabályozásáról lásd: Csák Csilla Hornyák Zsófia - Olajos István: Az Alkotmánybíróság határozata a mező- és erdőgazdasági földek végintézkedés útján történő örökléséről - Az örökléshez való jog sérelme, Jogesetek Magyarázata, 2018/1, megjelenés alatt; Hornyák Zsófia: Grunderwerb in Ungarn und im österreichischen Land Vorarlberg, Agrár- és Környezetjog, 2014/17, 62-69.; Hornyák Zsófia: Die Regeln der Erbfolge auf der Basis einer Verfügung von Todes wegen im landwirtschaftlichen Grundstückverkehr, JAEL, 2016/21, 4-27., doi: 10.21029/JAEL.2016.21.4; Hornyák Zsófia: A mezőgazdasági földek jogutódlásának anyagi jogi kérdései, Miskolci Jogi Sz̨emle, 2017/2, 124-136. Hornyák Zsófia: A földöröklés szabályozása egyes európai országokban, Miskolci Jogi Szemle, 2017/2. klnszm, 182-188. 


\section{Mi a helyzet a NATURA 2000 hálózat részét képező földek vagyonkezelésével? Védett-e a NATURA 2000 terület?}

A kérdés, illetve a természeti védettség alatt álló területek esetleges átruházásának problémája nem hagyta hidegen az Alkotmánybíróságot, és az indítványozó gondolatát továbbvíve, hivatalból értelmezte a Nemzeti Földalapba tartozó földrészletek hasznosításának részletes szabályairól szóló 262/2010. (XI.17.) Korm. rendelet 9. pontjának Alaptörvénnyel való összhangját. A 9. pont megsemmisitését kérték, mivel álláspontjuk szerint e rendelkezés sérti az Alaptörvény $\mathrm{P}$ ) cikk (1) bekezdését, valamint az Alaptörvény XXI. cikkét. A kezdeményező képviselők azt is sérelmezik, hogy az 1166/2015. (IX.21.) Korm. határozat - a Földet a gazdáknak! program - 1/d. pontja az értékesítési körből a Natura 2000 területeket nem veszi ki, ez pedig sérti a természetvédelmi területek speciális kezelését előiró, a cikk előző részében ismertetett elvek érvényesülését.

Az indítvány kapcsán az Alkotmánybíróság értelmezte a Natura 2000 területek kijelölésének speciális szabályozásának jelenlegi rendszerét. Az értelmezés kapcsán megállapítható, hogy a Natura 2000 terület egy európai jellegú természetvédelmi hálózat része. Fontos szerepe van abban, hogy megőrizze a mezőgazdasági földhasználat és a természetvédelmi célú földhasználat közti összhangot, természetvédelem céljainak megfelelően biológiai folyosóként múködve lehetőséget biztosítson a biodiverzitás jelenlegi szintjének fenntartására akkor is, ha a monokultúrára törekvő mezőgazdaság érdekei ezzel ellentétesek. A természeti állapothoz közeli területeken minimális emberi beavatkozással vagy emberi beavatkozás nélkül maradhat meg a biodiverzitás jelenlegi állapota, és az állam kötelezettsége a kijelölés kapcsán csak abban mutatható ki, hogy az adott területek a kijelöléskori védettségi szintje ne csökkenjen. A Natura 2000 területek kijelölésekor a kijelölést felügyelő európai hálózat arra törekedett, hogy a területek biológiai folyosó jellege és a jelöló fajok fennmaradása megfelelóen biztosíthatóak legyenek. A kijelöléskor nem volt szempont, hogy a kijelölt területek az adott ország természetvédelmi rendszerében milyen szerepet töltenek be: védett területek-e vagy csak az extenzív gazdálkodás következtében alkalmasak arra, hogy a biodiverzitás megőrzését szolgálják? A kijelölésben közremúködő szervezetek tehát ugyanúgy jelöltek ki állami és nem állami területeket Natura 2000 területté, ahol a terület használójának többletkötelezettsége a terület jelenlegi védettségi szintjének megtartása és az ezt 
biztosító földhasználat kereteinek biztosítása volt. ${ }^{23}$ A területhasználók sokkal kevésbé voltak korlátozva e területek használatában, mint a konkrét hatósági határozatokkal és gazdálkodás ellenőrzésével felügyelt természeti területek használói. A Natura 2000 területek használatának ellenőrzése kapcsán a kifizető ügynökség (Mezőgazdasági és Vidékfejlesztési Hivatal), majd jogutódjai (a kormányhivatalok agrár- és vidékfejlesztését segítő főosztályai) az előírások ellenőrzése kapcsán bevonták a természetvédelmi feladatokat ellátó nemzeti park igazgatóságokat is a területhasználat tényleges ellenőrzésébe. A földhasználattal járó kötelezettségek alapfeltétele azonban itt is a gazdálkodás folytatása volt és emellett a speciális korlátozások meghatározott idôre, tipikusan a támogatási ciklus végéig történő betartása.

Az ellenőrzés kapcsán a támogatás jogosságát vizsgáló támogatási és delegált feladatokat ellátó szervek abszolút nem voltak tekintettel arra, hogy a tulajdonos állami szerv vagy természetes személy, esetleg jogi személy volt-e. A biodiverzitáshoz ${ }^{24}$ kapcsolódó speciális előírások ugyanis a mindenkori használót terhelték, és ő igényelhette az általa használt területekre az állami támogatást. A tulajdonos anyagilag abszolút nem volt érdekelt abban, hogy az általa használatba adott területen betartják-e a támogatás speciális feltételeként előírt követelményeket.

Más a helyzet azonban, ha a földtulajdon és a földhasználat a tulajdonos kezében egyesül e területeket nézve, ugyanis akkor az erre vonatkozó támogatási előírások feltételeként előírt speciális használati kötelezettségek a tulajdonost fogják

${ }^{23}$ Lásd: Tilki Katalin: A természetvédelem magyarországi helyzete és jogi környezete, a Natura 2000 hálózat, Belügyi Sžemle, 2017/9, 72-88.; A tagállamok hatáskörrel és illetékességgel rendelkező hatóságainak kötelezettsége javaslatot tenni az Európai Bizottságnak a közösségi jelentőségű természeti területek jegyzékén szereplő természeti terület átminősítésére abban az esetben, ha valamely, e természeti területhez tartozó terület tulajdonosa kérelemmel fordult e hatóságokhoz e terület környezetromlására hivatkozva, amennyiben a kérelem azon a körülményen alapul, hogy az említett természeti terület - ezen módosított irányelv 6. cikke (2)(4) bekezdése rendelkezéseinek tiszteletben tartása ellenére - véglegesen nem tud hozzájárulni a természetes élőhelyek, valamint a vadon élő állatok és növények védelméhez vagy a Natura 2000 hálózat létrehozásához: C-301/12, Közigazgatási-Gazdasági Döntvénytár, 2016/3, 54-59. Az EMVAból finanszírozott Natura 2000 területet érintő kompenzációs támogatás iránti kérelem visszavonására az alkalmazásában és hatályában elsőbbséget élvező EK rendeleti szabályokat kell alkalmazni, mivel a tagállami jogszabály súlyosabb kötelezettségeket ír elő a kérelmezô számára: Kúria Kfv. IV. 35 403/2013, Közigazgatási-Gazdasági Döntvénytár, 2015/3, 5-7.; Cordula Mertens: Playing at multiple levels in biodiversity governance: The case of Hungarian ENGOs in Natura 2000, Society and Economy, 2013/2, 187-208.; Cseke Hajnalka: Zöld a pácban - Az Audi és a Natura 2000, Figyeló, 2011/30, 10-11.

${ }^{24}$ A biodiverzitással kapcsolatban lásd: Kis József - Barta Sándor - Elekes Lajos - Engi László - Fegyver Tibor - Kecskeméti József - Lajkó Levente - Szabó János: A pásztorok tudásának és világnézetének szerepe a biodiverzitás és az ökoszisztéma-szolgáltatások fenntartásában, Természetvédelmi Közlemények, 2016/22, 96-111. Némethy Sándor - Bartłomiej Walas: Bioenergy Crops as New Components of Rural and Agricultural Landscapes: Environmental and Social Impact, Biodiversity, Cultural Heritage and Economy, Journal of Central European Green Innovation, 2015/klnszm, 111-124.; Puskásné Jancsovszka Paulina: A KAP „zöld komponense” és a biodiverzitás, Lépésele a fenntarthatóság felé, 2015/1, 12-13.; Gencsi Zoltán: Biodiverzitás és természetvédelem a magyar Alföldön, Erdészeti Lapok, 2011/12, 374-375. 
terhelni. Ezért az értékesítés kapcsán oda kell figyelni arra, hogy a terület használójává váló és erre kötelezettséget is vállaló magántulajdonos tisztában legyen azzal, hogy a földhasználat speciális szabályainak megtartása nemcsak egy támogatási követelmény, hanem az értékesítő állam nemzetközi kötelezettségeinek megtartása is. ${ }^{25}$

Ezért az ilyen jellegű terület megvásárlásával földhasználata korlátozott lesz, aminek elmulasztása támogatási pénzek elvesztése mellett esetleges közigazgatási szankciókat eredményezhet. A természetvédelmi területnek nem minősülő Natura 2000 területek általános jellegű értékesítése során az értékesítő Nemzeti Földalap e követelmények betartására nem hívta fel a területekre pályázó földművesek figyelmét és ezáltal mulasztást követett el, melynek orvoslására az Alkotmánybíróság megállapította a szabályozás rendszerének mulasztásos alkotmánysértő voltát. 2018. június 30-ig határidőt adott az ilyen területekre vonatkozó szabályozás speciális szabályainak megalkotására, azonban tekintettel arra, hogy a Natura 2000 területek nem részei a magyar természetvédelmi rendszernek az indítvány szerinti kezdeményezést elutasította.

Az Alkotmánybíróság az előterjesztő Szabó Marcel6 alkotmánybíró komoly munkájának következtében a természetvédelmi és környezetvédelmi jog szempontjából példaértékű határozatot alkotott, amely alapjául szolgálhat a Natura 2000 területekre vonatkozó jogi kutatásoknak. E határozat kapcsán jól értelmezhető a természetvédelem területén a hazai és európai természetvédelmi jog eltérő szabályozási tárgya és szabályozási módszere. Míg a hazai természetvédelmi jog a területvédelem és a fajvédelem rendszerein alapul, az európai természetvédelmi jog a környezetvédelemhez hasonló rendszerszintû szabályozást alkot, és ennek a két rendszernek egy különös átfedése a Natura 2000 területek, melyek jól azonosíthatóak a természetvédelmi törvényben is szabályozott biológiai folyosó, e cikk előző részében már kifejtett fogalmával. Az Alkotmánybíróság szigorúan értelmezte a természetvédelmi jellegű területekre vonatkozó hazai környezetjog rendszerében kialakított cselekvési kötelezettségeit. Csak a természetvédelmi területek állami kezelésére és állami tulajdonba vételére van kötelezettsége, csak az ilyen területek szabályozási rendszerére vonatkozik a visszalépés tilalma, és ennek intézményvédelmi rendszere, a Natura 2000 terület nem az Alaptörvény által garantált természetvédelmi terület.

A magyar természetvédelmi jog rendszerében átmenetet képez a természeti védettség alatt álló és a szabadon művelhető területek között. Az ilyen területek speciális kezelésére azonban a kapcsolódó uniós irányelvek betartására vonatkozó előírások kapcsán speciális kötelezettsége van az államnak. E kötelezettség jól körülírható a Natura 2000 területekre vonatkozó speciális vidékfejlesztési támogatások előírásai rendszereként. Ezen előírások betartása azonban az állam számára jogalkotási kötelezettségben testesül meg, tekintettel a 79/409/EGK, ún. madárvédelmi és a 43/92/EGK, ún. élőhelyvédelmi irányelv megfelelő átültetésére vonatkozó kötelezettségek kapcsán. A speciális helyzet itt abból adódik, hogy a tulajdonszerző

25 Lásd: 28/2017. (X.25.) AB határozat 15-18. pontjait. Itt számos nemzetközi jogi elôírást elemez az Alkotmánybíróság.

${ }^{26}$ Szabó Marcel: Az európai jog és a nemzetközi jogrend - hierarchia és összefonódás, Alllam-és Jogtudomány, 2012/2-3, 191-211.; Szabó Marcel: The Implementation of the Judgment of the ICJ in the Gabcikovo-Nagymaros dispute, Iustum Aequum Salutare, 2009/1, 15-26. 
természetes személy, egyúttal a terület sajátjakénti használójává válik. Mivel e két jogilag szabályozott státusz egy kézben egyesül, így a speciális előírások jogi betartatására is speciális szabályokat kell alkotni. Véleményem szerint ez az előírásrendszer a Földet a gazdáknak! program befejezésével mindenképpen utólagos szabályozásnak minősül, és amennyiben e kötelezettségek kapcsán az addig korlátlanul földet használó tulajdonos földhasználata elnehezül, a szabályozás utólagos jellegéből adódóan felvetheti a szerződéskötéssel okozott kár érvényesítésének lehetôségét is. A másik lehetőség, hogy a körülmények elnehezülése miatt a tulajdonos elállván a szerződéstől követelheti a terület ismételt állami tulajdonba vonását. Ebben az esetben azonban a kifizetendő kártalanítás összegének megállapítása nem a terület tényleges értékén, hanem a károsult megfelelő ellentételezésén kell, hogy alapuljon.

Összefoglalóan elmondható, hogy a védett területek állam tulajdona, és ehhez kapcsolódó speciális vagyonkezelése, és ennek megvédésére való törekvés a magyar természetvédelmi jog olyan vívmányának tekinthető, mely 23 év óta a magyar jogrendszer része, és aminek a védelmében más kialakított intézményektől eltérően, ${ }^{27}$ az Alkotmánybíróság konzekvensen alkalmazza a visszalépés tilalmát az állami szervek jogalkotási szabadságának meghatározása kapcsán.

27 A Jövő Generáció Országgyúlési Biztosa poszt megszüntetésével, és azzal, hogy a területért felelős helyettes ombudsman hivatali apparátusa, és költségevetése is jelentősen csökkent, a környezetvédelem egy jelentős, intézményesített területén következett be visszalépés. Ezt a tényt az Alkotmánybíróság hivatalból nem észlelte. (A szerző véleménye.) 